WIAS Discussion Paper No.2007- 005

\title{
Family Firms and Firm Performance: Evidence from Japan ${ }^{1}$
}

\author{
March 2008
}

\section{Takuji Saito}

Kyoto Sangyo University and WIAS

Waseda Institute for Advanced Study (WIAS)

1-6-1 Nishiwaseda, Shinjuku-ku, Tokyo 169-8050, Japan

Tel: +81-3-5286-2460 ; Fax: +81-3-5286-2470

\footnotetext{
1 The author is grateful to Kazuki Yokoyama, Hiroyuki Itami, Hiroshi Osano, Mitsuaki Okabe, Katsuyuki Kubo, Shin'ichi Hirota, Hideaki Miyajima, Hiroyuki Odagiri, Yasuhiro Yonezawa, Naohito Abe, Hiroyuki Okamuro, Yupana Wiwattanakantang, an anonymous referee, seminar participants at Hitotsubashi University and Waseda University, and participants at the annual meeting of the Japanese Economic Association and Nippon Finance Association, for their helpful comments. This research was partly financed by JSPS (Japan Society for the Promotion of Science) and the 21st Century Center-of-Excellence Project on "Creating New Legal System for Corporation and Society" of Waseda University. Needless to say, I am solely responsible for any remaining errors.
} 


\title{
Family Firms and Firm Performance: Evidence from Japan
}

\begin{abstract}
We examine the performance of firms that are controlled by founding families in Japan. We construct a new dataset on founding families, which includes data on founding family ownership, family management, and generation of family senior managers. We find that about 36\% of listed firms are managed by the founder or his descendant, and founding families are the largest shareholder in about $25 \%$ of listed firms. We empirically find that family firms managed by founders are traded at a premium. After the retirement of founders, the results are mixed. The performance of family firms both owned and managed by the founder's descendants is inferior to that of nonfamily firms. In contrast, the performance of family firms owned or managed by the founder's descendants is superior to that of nonfamily firms.
\end{abstract}

JEL Code: G32, M13

Keywords: Family Firm; Ownership Structure; Corporate Governance

Corresponding author. Tel.: +81-75-705-1761

E-mail address: tsaito@cc.kyoto-su.ac.jp 


\section{Introduction}

Family firms are unique among publicly traded firms. Many founding families hold both a large stake of equity and senior management positions in their firms. In other words, ownership and control is not separated in many family firms. Another characteristic of family firms is succession of control of the business to the founder's descendant. Succession to one's descendant is controversial. Burkart et al. (2003) and Perez-Gonzalez (2006) suggest that unrelated senior managers are superior. To the contrary, Laband and Lentz (1986) and Lentz and Laband (1990) suggest the importance of intangible transfers between generations. Thus, a family firm is different from the well-known "Berle and Means firm”, where ownership is dispersed among small shareholders, but control is concentrated in the hands of professional managers.

Over the past few decades, a considerable number of studies have been conducted on how to mitigate agency costs between managers and shareholders in the "Berle and Means firm”. In contrast, only a few studies have been conducted so far on family firms, especially in developed countries. However, it is important to study family firms because they are common among public firms not only in developing countries, but also in developed countries (La Porta et al., 1999). Faccio and Lang (2002) find that $44 \%$ of firms in Western Europe are controlled by families. Anderson and Reeb (2003) show that founding families are present in one-third of S\&P 500 firms in the US.

Several recent studies have found a relationship between family firms and firm performance across countries. However, the results are mixed. It is important to generate stylized facts on family firm from different countries, because various characteristics of the country, for example, the legal system, affect family firms (Bertrand and Schoar, 2006). Thus, we may be able to understand the differences by generating international evidence on family firms.

In this paper, we aim to clarify the relationship between family firm and firm performance in Japan by classifying the family firms based on the characteristics of the management and ownership. Family firms are not uniform, especially after the founder retires, when a variety of structures may come into play. For example, after founder retired, his descendant can choose to run the business or to hire the professional nonfamily manager. In addition, the founding family could choose between making a 
seasoned equity offering (SEO) or not. SEO may boost expansion of the business, but lower the ratio of family ownership and undermine the ascendance of the founding family. In order to take the characteristics of family firms into account, we classify family firms by ownership, management, and number of generations of the founding family, and estimate the relationship between the various categories of family firms and firm value. To the best of our knowledge, this is the first large-sample study to examine the relationship between family firms and firm performance in Japan.

Using data for 1,818 publicly traded firms in Japan from 1990 to 1998, we construct a unique dataset for founding families that includes founding family ownership, family management, and the generation of family senior managers. We find that founding families are a prevalent and important class of shareholders and senior managers in Japan. In our sample, 738 firms (40\% of all listed firms) have a shareholder related to the founding family among the twenty largest shareholders. In 550 firms (30\%), the founding family is the owner of at least 5\% of the firm's equity. In 461 firms (25\%), the largest shareholder is the founding family. In 659 firms (36\%), the senior manager (president or chairman) is the founder or his descendant. In 423 firms (23\%), the largest shareholder is the founding family and the senior manager is from the founding family. In addition, we find that there are many family firms where ownership and management are separated in Japanese public firms. When founders are still active, the founding family is the largest shareholder in $80 \%$ of firms. However, after succession of the management position to a founder's descendant, the founding family is the largest shareholder in about $55 \%$ of firms.

The empirical results indicate that the family firms slightly outperform nonfamily firms in Japan. However, the family firm premium mainly results from the active founders. After retirement of founders, the results are mixed. We find that the performance of family firms both owned and managed by the founder's descendants is inferior to that of nonfamily firms, but the performance of family firms owned or managed by the founder's descendants is superior to that of nonfamily firms. We also find that investors devalue family firms managed by descendants by marriage compared with family firms managed by blood descendants. 
The structure of the paper is as follows. In the next section, we review previous studies, and present our arguments on family firms. In section 3, we describe our data and provide summary statistics. We present the empirical results in section 4 . Section 5 explores the robustness of the results, and section 6 provides a summary and conclusion.

\section{The Family Firm}

\section{2-1. Previous Studies}

Recently, the costs and benefits of family firms where have been discussed widely, based on the classic owner-manager agency problem (Berle and Means, 1932; Jensen and Meckling, 1976) and the agency problem between large and small shareholders. In many family firms, the founding families hold a large equity stake and also occupy senior management positions. The potential benefit of managers having large ownership stakes is that it provides them with having strong financial incentives to improve firm performance. In addition, Leland and Pyle (1977) suggest that high levels of managers’ ownership help signal firm's quality when information asymmetries exist between managers and outside shareholders. ${ }^{2}$

The potential cost of large concentrated shareholders is that they take actions that pursue private benefits at the expense of other shareholders and firm performance (Shleifer and Vishny, 1997). Several papers show that founding families seek private benefits from the management of their family firms. Perez-Gonzalez (2006) and Bennedsen et al. (2007) show that nepotism within a family firm hurts firm performance. Perez-Gozalez (2006) examines 500 US firms and finds that when the current family CEO announces his/her resignation, the share price rises sharply if the incoming CEO is an external manager and fell if it is another family manager. Bennedsen et al. (2007) find that in Denmark, family succession lowers firm performance. Bertrand et al. (2005) show that in Thailand, a wider involvement of family members in family firms lowers firm performance.

These private benefits of control are strongly affected by the level of legal protection given to minority shareholders (Dyck and Zingales, 2004). Burkart et al. (2003) model

\footnotetext{
${ }^{2}$ Bertrand and Schoar (2006) discuss family firms from a broad perspective.
} 
the control succession decisions of family firms and argue that founding families choose to preserve control within the family if the level of protection given to minority shareholders is weak. Consistent with this prediction, Claessens et al. (2000) and Faccio and Lang (2002) show that a family firm is the dominant form of ownership structure in Asia and continental Europe, where the protection of minority shareholders is, in general, weak.

Several studies find a relationship between family firms and firm performance. Anderson and Reeb (2003) investigate the relationship between family firms and firm performance in the US. They find that family firms perform better than nonfamily firms and conclude that family firms have an effective organizational structure. Moreover, McConnaughy et al. (1998) find that in the US, family firms are also more efficient and valuable than nonfamily firms. Maury (2006) shows that in Western Europe, family firms managed by the founding family are more profitable than nonfamily firms. In contrast, Claessens et al. (2002) show that in Southeast Asian countries, family firms underperform relative to nonfamily firms. Cronqvist and Nilsson (2003) find that in Sweden, the value of family firms is largely discounted. Barth et al. (2004) show that in Norway, family firms owned and managed by the founding family are less productive than nonfamily firms.

More recent studies indicate the importance of the generation of the family management and family structure in family firms. Villalonga and Amit (2006) examine the relationship between family firms and Tobin's $q$ in the US. They conclude that founder-CEO firms outperform nonfamily firms however, when descendants serve as CEOs, firm value is destroyed. Morck et al. (2000) find that in Canada, family firms controlled by an heir exhibit poor financial performance. Bloom and Van Reenen (2007) find that in France, Germany, the UK, and the US, poor management practices are more prevalent in family firms managed by a founder's descendant. A notable exception is the research by Sraer and Thesmar (2007), who, in France, find a premium for family firms, even if they are managed by descendants of founders. 


\section{2-2. Definition of Family Firm}

Family firms are firms where the founding family has an influence over firm policy, corporate strategy, personnel issues, and so on, through ownership and participation in management. We define family firms as those in which the founder or his descendant is a president or chairman and/or the founding family is the largest shareholder in the firm. ${ }^{3}$ This definition is slightly different from that used in previous studies in the US. Anderson and Reeb (2003) and Villalonga and Amit (2006) define family firms as firms where the founder or a member of the founding family is an officer, a director, or the owner of at least $5 \%$ of the firm's equity. ${ }^{4}$ In Japan, Prowse (1992) shows that most of firms have a blockholder like a main bank, mochiai, or keiretsu. Therefore, if we apply the definition of previous studies, many founding families in Japan do not exert influence over the firm as a shareholder, even if they have a stake exceeding $5 \%$ in the firm. In terms of management, there are few outside directors and a strict hierarchy within boards in Japanese firms. This structure is needed to assume power as president or chairman for controlling the firm.

\section{2-3. Family Firm Type}

In this paper, we classify the family firms based on the characteristics of the management and ownership in order to clarify the relationship between family firm and firm performance. The founding family could affect firm performance in various ways. For example, after the founder's retirement, the founder's descendant can choose to run the business and enhance firm value by good management, or to hire a professional nonfamily manager and improve the firm performance by monitoring this manager through being a large shareholder.

Therefore, we classify the family firm into three type family firms, family firm $(M \& O)$, family firm $(O)$, and family firm $(M)$. Firstly, the family firm $(M \& O)$ is a firm where the senior manager (president or chairman) is either the founder or his descendant,

\footnotetext{
${ }^{3}$ We define family management as those firms in which the founder or his descendant is president or chairman.

4 Later, we will determine the sensitivity of our results when we use alternative definitions of family firms.
} 
and the founding family is the largest shareholder. In this type of firm, the founding family has influence through both management and ownership. According to classical agency theory, a benefit of the family firm $(M \& O)$ is that it has strong financial incentives to improve firm performance because they have a lot of equity. However, the main purpose of shareholdings by the founding family is more likely to preserve their control rather than invest for capital gain. In this case, family firm (M\&O) might not pay enough attention to firm performance and take actions that benefit the founding family at the expense of other small shareholders. For example, even if the son does not demonstrate aptitude for management, the family can still promote him to senior manager. In addition, family firm (M\&O) might take risk reduction strategy, which can impose costs on diversified minority shareholders due to the concentration of the founding family's wealth in the equity of the "family firm (M\&O)”. If these costs of the family firm $(M \& O)$ overtake their benefit, family firm $(M \& O)$ is devalued in the market.

Second, the family firm (O) is a firm where the founding family is the largest shareholder, but the senior manager is not a family member. In this type of firm, the founding family has influence only through ownership. Hence, the founding family could monitor and discipline a manager as a large shareholder, and contribute to the firm performance (Shleifer and Vishny, 1986).

Third, the family firm ( $M)$ is a firm where the senior manager is from the founding family, but the founding family is not the largest shareholder. In other words, there is a largest shareholder other than the founding family. In this type of firm, it is difficult to take actions that benefit the founding family at the expense of shareholders and firm performance, since a family senior manager is constrained by other large shareholders. However, a family senior manager may not have a strong financial incentive to improve firm performance because the family ownership level is low. Based on the agency problem, we can predict that the performance of this type of family firm will not differ from that of nonfamily firms. However, if the senior manager from the founding family has an inherent incentive or ability in the founding family, this type of family firm could outperform nonfamily firms. Anderson et al. (2003) argues that the family's sustained presence in the firm creates powerful reputation effects that provide incentives for family managers to improve performance. Davis et al. (1997) suggests that family 
members act as stewards and, as such, identify strongly with the firm and view firm performance as an extension of their own well-being.

\section{2-4. Generation and Affinity}

In many family firms, we can observe family succession. A typical example is when the family senior manager steps down, and his eldest son is promoted to the post of senior manager. The one problem with family succession is that family firms pick senior managers from a small and less competitive pool of family heirs. Perez-Gonzalez (2006) shows that family successions cause a decline in firm performance in the US. Adams et al. (2004) and Fahlenbrach (2004) show that founders and descendants have a very different impact on firm performance.

That said, descendants might have family-specific capital with which to contribute firm value. Laband and Lentz (1986) and Lentz and Laband (1990) show the importance of intangible transfers between generations that take the form of specialized knowledge, goodwill, brand (or name) loyalty, and other types of family-specific capital. The value of this family-specific capital can be captured only by children who follow their parents into the family firm. Dunn and Holtz-Eakin (2000) show strong roles for family-specific capital and the transmission of these skills within families in enhancing the probability of making a transition to entrepreneurship. Hence, we classify family management into founder management, descendant management, 2nd generation management, and 3rd generation management. ${ }^{5}$

In addition, we distinguish descendant-in-law senior managers (descendant-in-law management) from descendant-in-blood senior managers. By recruiting a capable man through marriage, the cost of a restricted executive pool may be mitigated. In the Edo era (1603AD-1867AD), merchant families in the Senba area of Osaka celebrated the birth of a daughter because it enabled them to recruit and train a capable man through marriage to the daughter. This ability to assess experienced adults before taking them on can be contrasted with the difficulty of identifying the ability of a son before he grows up. In the present period, several family firms are managed by descendants-in-law. For

\footnotetext{
5 The definitions are summarized in Table 1 and section 3.
} 
example, in Matsushita Electric Industrial Co., the founder Kounosuke Matsushita had only one daughter. She married Masaharu Hirata, who was a graduate of Tokyo University and worked at the Mitsui Bank. After the marriage, he joined Matsushita Electric Industrial Co., and he became the president at age 49. In Suzuki Motors, the 2nd and 3rd presidents are sons-in-law of the founder Michio Suzuki. The 4th president, Osamu Suzuki is the son-in-law of the 2nd president. Now, Osamu Suzuki is chairman, and his first son and the husband of his first daughter are on the board of Suzuki Motors. If this is the case, we can predict that family firms managed by descendant-in-law senior manager outperform family firms managed by descendant-in-blood senior managers.

\section{2-5. Terms to Link Family Firm Type to Generation}

We use special terms to indicate the relationship between family firm type and the generation of the family senior managers. When the founder is active as president or chairman and the founding family is the largest shareholder, we classify this firm as a founder firm $(M \& O)$. When the founder is active, but the founding family is not the largest shareholder, we classify this firm as a founder firm (M). To use consistent terminology, we use the terms descendant firm (M\&O), descendant firm (M), 2nd generation firm (M\&O), 2nd generation firm (M), 3rd generation firm (M\&O), 3rd generation firm (M), descendant-in-law firm $(M \& O)$, and descendant-in-law firm $(M)$.

When the founder is still active, ownership tends to be concentrated in the hands of the founder in most family firms. Therefore, we predict that most founder firms belong to founder firm $(M \& O)$. However, it is not necessarily true that the ownership is concentrated in the hands of the founding family after the founder retires because, as years pass, family ownership would be dispersed by the succession ${ }^{6}$, seasoned equity offerings and divestment of shares. Therefore, we predict that in the descendant generation, family firms may branch into descendant firm (M\&O) and descendant firm (M) as a result of the founding family's various choices.

For the founding family, making seasoned equity offerings is one of the most important decisions which affect their control and the firm performance. Seasoned

${ }^{6}$ Maximum succession tax rate was 70\% until 2002 and became 50\% after 2002. 
equity offerings may deliver an expansion of the business, but also lower the ratio of family ownership, and undermine the ascendancy of the founding family. In a descendant firm $(M \& O)$, founding families may have chosen not to make seasoned equity offerings for fear of diluting family ownership. If this is the case, these types of firms may be traded at a discount relative to nonfamily firms. In a descendant firm $(M)$, the founding family may accept the dilution of family ownership caused by seasoned equity offerings for the expansion of the business. Therefore, this type of family firm could outperform the descendant firm $(M \& O)$. However, the founding family would sell their shares if they believed the prospects of their business were fading. If this is the case, this type of family firm may be traded at a discount relative to nonfamily firms and a descendant firm $(M \& O)$.

Succession to descendants is also one of the important decisions for founding family. Previous literatures (Perez-Gonzalez, 2006; Villalonga and Amit, 2006) indicate that in family firms descendant senior managers harm the firm performance, because they can assume the senior manager even if their managerial ability is inferior. However, in descendant firm (M), large shareholders other than founding family might prevent the inferior descendants from becoming the senior manager. In this case, we can predict that descendant firm (M) outperforms descendant firm (M\&O).

We investigate the effects of family firms, family ownership, family management, family generation, and various types of family firms to firm performance, using firm-level data on Japanese publicly traded firms in the following sections.

\section{Sample and Data}

\section{3-1. Sample and Family Firm Data}

In our investigation, we begin with all the firms included in The Corporate Financial Databank (compiled by the Development Bank of Japan) in 1990, which includes all the companies listed in both the first and second sections of the stock exchanges of Tokyo, Osaka, and Nagoya. From this list of firms, we exclude financial firms (187 firms) and public utility firms (19 firms) due to the difficulty involved in calculating Tobin's $q$ in the bank sector, and government regulations that potentially affect firm performance and the relation between the founding family and the firm. Our sample 
period is 1990-1998. The final sample includes 1,818 unique firms and 15,950 firm-years from 1990 to 1998. In 1990, the number of listed firms in Japan was approximately 2,100 (including financial firms, public utility firms, and the firms listed in other stock exchanges). Therefore, our sample is almost equal to the total number of listed firms in Japan. This sample set enables us to obtain more general and comprehensive evidences on family firms in Japan.

To identify and classify family firms, we collect family ownership and management data for all the sample firm-years. ${ }^{7}$ Family ownership is defined as the percentage of shares held by the founding family as a group. To construct family management data, we investigate the relationships of all the senior managers and founding families. Based on this management data, we define family management as those firms where the founder or his descendant is the president or chairman. Next, we distinguish between the generation and affinity of family management to derive founder management, descendant management, 2nd generation management, 3rd generation management, and descendant-in-law management. ${ }^{8,9,10}$

Using these family ownership and management data, we now build on the terms identified in section 2-5 to compile the following: family firm, family firm (M\&O), family firm (M), family firm (O), founder firm (M\&O), founder firm (M), descendant firm $(M \& O)$, descendant firm $(M)$, descendant-in-law firm (M\&O), descendant-in-law firm (M), 2nd generation firm (M\&O), 2nd generation firm (M), 3rd generation firm $(M \& O)$, and 3rd generation firm $(M)$.

\section{3-2. Firm Performance and Control Variables}

Our primary performance measure is Tobin's $q$, which has the advantage of indicating any possible corporate governance problems and potential growth. We

\footnotetext{
${ }^{7}$ Refer to the Appendix for more detailed explanations on the construction of data on family ownership and management.

${ }^{8}$ When both president and chairman are members of the founding family, we use the older generation. For example, when the chairman is founder and the president is his son (2nd generation), we define this firm as founder management.

9 There are several senior managers who are a brother of the founder. We define them as 2 nd generation.

10 3rd generation management also includes 4th or later generation management.
} 
estimate Tobin's $q$ as the firm's market value (the sum of the market value of equity and book value of leverage) divided by the replacement cost of assets (the real value of total assets).

In Japan, the firm discloses only the book value of assets. When using the book value to measure Tobin's q, systematic differences may be caused by firm age because Japan experienced high inflation in high growth period and sharp rises and falls in land values around 1990. This problem is serious for our research because, as we show in the next section, firm age significantly differs between family firms and nonfamily firms, and between the founder firm and the descendant firm. Therefore, we try to calculate the real value of total assets following Hori et al. (2006) and Miyajima et al. (2001).

The data needed to calculate Tobin's $q$ and market value of assets is obtained from The Corporate Financial Databank compiled by the Development Bank of Japan.

The definition of family firm variables, performance measures, and other control variables are explained at Table 1 . All control variables except beta and idiosyncratic risk are obtained from The Corporate Financial Databank, compiled by the Development Bank of Japan. Beta and idiosyncratic risk is calculated using the Kabuka CD-ROM (published by Toyo Keizai Shinposya). All variables are adjusted to constant yen (the base period is March 2000) using the wholesale price index.

\section{3-3. Summary Statistics}

Table 2 presents the distribution of family ownership and family management for the 1,818 sample firms in 1990. In the sample, 738 firms (40\%) have a shareholder related to the founding family amongst the twenty largest shareholders. In 550 firms (30\%), the founding family is the owner of at least $5 \%$ of the firm's equity. The founding family is largest shareholder in 461 firms (25\%). In terms of management, the senior manager is the founder or a member of founding family in 659 firms (36\%). As a whole, family firms constitute about 40\% (697 firms) of our sample firms. These results show that founding families are a prevalent and important class of shareholders and senior managers in Japanese public firms.

Of the 697 family firms, 423 firms are classified into family firm (M\&O), 236 firms are classified into family firm (M), and 38 firms are classified into family firm (O). 
Compared with other countries, it is interesting that there are many family firms ( $M$ ) where the senior manager is from the founding family, but ownership is not concentrated in the hands of the founding family in Japan. In 46 firms with a family senior manager, shareholders related to the founding family are not included in the list of the twenty largest shareholders, and in the quarter of firms with a family senior manager, family ownership is below $5 \%$.

Table 3 presents the prevalence of the family firm and three types of family firms by two-digit industry. Family firms are present in $85 \%$ of industries, indicating that family firms operate in a broad array of industries. However, we note that family firms appear to be the prevalent form in food, lumber and wood products, printing and publishing, metal products, precision instruments, building, wholesale and retail sales. In contrast, there are few family firms in oil, iron and steel, and railroad transportation. These results suggest the importance of the controlling industry's affiliation in the empirical analysis.

Table 4 provides means, medians, standard deviations, minimum values, and maximum values for the variables for all firms in the sample in 1990. Table 5 provides descriptive statistics, broken into family firms and nonfamily firms, and three types of family firms. The last two columns show the results of difference of means and medians tests between family firms and nonfamily firms. ${ }^{11}$

The mean Tobin's $q$ of family firms is 0.1 higher than that of nonfamily firms, and the difference is statistically significant at the $1 \%$ level. Similarly, the difference in the median is statistically significant at the $1 \%$ level. When we use industry-adjusted tobin's $q$, the differences are also statistically significant. These results suggest that family firms are better performers than are nonfamily firms in Japan. Across the various industries, the Tobin's $q$ of family firms is higher than nonfamily firms in 20 industries. ${ }^{12}$ In six industries, these differences are statistically significant at the conventional level. $^{13}$

${ }^{11}$ We use $t$-tests to compare the means, and Wilcoxon rank-sum tests to compare the medians.

12 The 20 industries are Textiles \& Apparel, Chemicals, Rubber, Iron \& Steel, Metal Products, General Machinery, Electric Appliances, Transportation Equipment, Precision Instruments, Other Products, Dredging, Wholesale Trade, Retail Trade, Railways, Road 
Family firms are significantly smaller in terms of the mean and median of assets and sales compared to nonfamily firms. Family firms do not appear to use debt differently than nonfamily firms. Rows 19 and 20 of Table 5 show firm age since foundation and IPO. In our sample, the oldest firm is Surugaya, founded by Zen'uemon Okamoto in 1461. Surugaya was still a family firm in our sample period. ${ }^{14}$ Successive presidents are from the Okamoto family. The median firm age since foundation and IPO of family firms is younger than that of nonfamily firms. This characteristic may raise a concern that the higher Tobin's $q$ of family firms may simply reflect different growth stages, because Tobin's $q$ varies positively with growth opportunities and young firms may have more of these. Therefore, we need to account for firm age in our regression analysis. The equity ownership by nonfamily shareholders is significantly lower in family firms than it is in nonfamily firms. It is surprising that a half of nonfamily firms have parent firms that have more than $15 \%$ equity. In other words, it is only $30 \%$ of firms among all Japanese public firms that have a hired senior manager and a dispersed ownership structure.

Columns 3 to 8 provide descriptive statistics of three type family firms. The mean and median family ownership of family firm (M\&O) is highest among three types of family firms. Surprisingly, average family ownership of family firm (M) is $3.98 \%$ and the median is $2.74 \%$. Next, we compare the generation of senior managers. Consistent with our prediction, $80 \%$ of founder management firms belong to family firm ( $M \& O)$. In contrast, the ratio of 2nd generation management firms belonging to family firm (M\&O) is about $60 \%$ and 3rd generation firms belonging to family firm (M\&O) is about $50 \%$. Thus, as years pass, family ownership would be dispersed, and the corporate governance of family firms would be transformed.

Passenger Transport, Warehousing, Films \& Amusement, Business Services, Information Services, and Other Services.

13 The six industries are Textiles \& Apparel, Iron \& Steel, General Machinery, Electric Appliances, Wholesale Trade, and Information Services.

14 In 2005, the president of Surugaya was arrested for illegally issuing new equity. As a result, Surugaya was delisted from the Tokyo Stock Exchange, and a nonfamily member became president. 
The mean and median firm performance of family firm $(M \& O)$ is highest among three types of family firms. This result would be caused by the difference in growth opportunities, because family firm $(M \& O)$ is younger than the others. The scale of family firm $(M \& O)$ is lowest among the three types of family firms. This result may be caused by differences in firm age too. Although not shown in the table, the mean and median assets of 2nd generation firm (M) are significantly larger than that of 2nd generation firm $(M \& O)$, and the median assets of 3rd generation firm $(M)$ is significantly larger than that of 3rd generation firm (M\&O). These results may be caused by the founding family’s attitude toward seasoned equity offerings.

Table 6 provides descriptive statistics of family firms, broken down by the generation of family management. The last two columns show differences in the means and medians between founder management and descendant management. The mean and median Tobin's $q$ of founder management is significantly higher than that of descendant management. Mean family ownership of founder management is about $19 \%$ and the founding family is the largest shareholder in most of them. By comparison, mean family ownership of descendant management is about $12 \%$ and about half of them have another largest shareholder. Row 4 of descendant management shows that descendant-in-law senior manager is not scarce. About $10 \%$ of descendant management firms take on a daughter's husband as senior manager.

In summary, there are significant differences in performance, size, capital structure, firm age, and family ownership between family firms and nonfamily firms, and within family firms. In the next section, we examine the relationship between family firms and firm performance using univariate and multivariate analysis.

\section{Family Firms and Performance}

Table 7 presents the univariate statistical analyses. Panel A provides the mean and median Tobin's $q$ when the sample of firms in 1990 is classified into four groups according to the founding families' equity ownership and management. The mean and median Tobin's $q$ for family firm $(M \& O)$ and family firm $(M)$ are significantly greater than the mean and median Tobin's $q$ for nonfamily firm. The mean and median Tobin's $q$ for family firm $(O)$ are larger than those for nonfamily firm; however these differences 
are insignificant at the conventional level. Panel B provides the mean and median Tobin's $q$ based on the founding families' equity ownership and generation of the senior managers from the founding family. When the founder is still the firm's president or chairman, Tobin's $q$ is higher than that of nonfamily firm. However, the differences between nonfamily firm and founder firm (M) that has others and not the founding family as the largest shareholder are insignificant. When the founder's descendant becomes the senior manager after the founder has retired, the mean and median Tobin's $q$ of 1.51 and 1.36 , respectively, for descendant firm $(M)$ are significantly greater than the mean and median Tobin's $q$ of 1.41 and 1.24, respectively, for nonfamily firm; however, the mean and median Tobin's $q$ of descendant firm $(M \& O)$ are lower than those of nonfamily firm.

The univariate statistics suggest that the performance of family firms is affected by the equity ownership of the founding family and the generation of senior managers from the founding family. However, the above univariate tests do not control the other determinants of family firms and Tobin's $q$. In the next, we extend our analysis to a multivariate setting. Tables 8 and 9 report the results of multivariate OLS regressions to investigate the relationship between family firms and firm performance. ${ }^{15}$ We use Tobin's $q$ as our dependent variable. ${ }^{16}$ The independent variables are various family firm variables, control variables, industry dummy variables, and year dummy variables. We use the natural log of assets, leverage, the natural log of firm age since from foundation, beta, related firm 1 dummy, related firm 2 dummy, and affiliated firm dummy as control variables. ${ }^{17}$ Related firm 1 dummy, related firm 2 dummy and affiliated firm dummy indicate the presence of the large shareholder other than founding

15 The standard errors are clustered by firm level. In all regressions, we do not use the firms that have a Tobin's $q$ below the 1st percentile and above the 99th percentile, in order to exclude outliers.

16 If we use industry-adjusted Tobin's $q$ or simple Tobin's $q$ that are calculated using the book value of assets, the results are similar, but they are less significant.

17 When we use alternative sets of control variables, the results of family firm variables remain unchanged. We use sales instead of total assets, and firm age since IPO instead of firm age since foundation. In addition, we attempt to control firm size and firm age, using each of the 10 percentile group dummy variables. 
family. Industry dummies and year dummies are included to control for industry and time effects. ${ }^{18}$ Our data spans from 1990 to 1998 and covers 1,818 firms.

In Table 8, we estimate the performance of the firms, controlled by founding family. We find that family firms slightly outperform nonfamily firms in Japan. In column (1), the family firm dummy, which takes the value of 1 if the senior manager is a founding family member and/or largest shareholder is the founding family, is positive and significant at the $10 \%$ level.

In order to detect what feature of the founding family contributes to this superior performance, we examine family ownership and family management effects on firm value in column (2) and (3). In column (2), we use family ownership, which is a measure of the share ratio held by the founding family. We find a positive and significant effect for family ownership. ${ }^{19}$ In contrast with this result, the effect of family management in column (3) is positive, but not significant at conventional levels.

However, these results do not conclude that passive family control creates firm value, but that active family control does not contribute to firm value. As shown in section 3, there are many family firms both owned and managed by the founding family. Family ownership with and without family management has different implications. High family ownership of firms managed by the founding family may indicate the possibility of expropriation from small shareholders. On the other hand, high family ownership without family management may indicate the presence of an outside large shareholder. Therefore, we classify family firms into three types of family firms: family firms (M\&O), family firms (M), and family firms (O). Column (4) of Table 8 shows the performance of these family firms. We find that family ownership contributes to firm performance only when the senior manager is a nonfamily member. In other words, large founding family shareholders plays a significant role in monitoring and

18 Pharmaceutical firms are prone to have a higher Tobin's q. Therefore, we distinguish the pharmaceutical industry from the chemicals industry.

19 Morck et al. (1988) show that the relationship between ownership structure and firm performance is nonlinear. Therefore, we include the square of family ownership in addition to family ownership. The effect of the square of family ownership is negative. However, in the interval of family ownership (maximum is 64.29\%), the total marginal effect of family ownership is always positive. 
disciplining hired managers. In contrast, family firms $(M \& O)$ and family firms $(M)$ do not have significant effects on firm value. These results are not consistent with the results of the univariate test, where the mean and median Tobin's $q$ of family firm (M\&O) are significantly superior to those of nonfamily firms. This fact indicates that the results of the univariate test might be the result of the substantial differences in age, size, and industry between family and nonfamily firms.

The results we have reported so far do not distinguish between generations of family senior managers. Nevertheless, previous studies show that founders have an inherent impact on firm performance. Therefore, we investigate these differences caused by the generation of the founding family in detail in Table 9.

In column (1), we classify family management into founder management and descendant management. The result is striking. We find that there is positive association between founder management and firm value but negative association between descendant management and firm value. The coefficient on founder management is strongly positive and significant at the $1 \%$ level, but descendant management is negative and significant at $5 \%$ level. The lower panel shows the result of a test of the null hypothesis that founder management and descendant management have the same effects on firm value. The result of this test shows that the null hypothesis is rejected at the $1 \%$ level. In other words, the performance of founder management is significantly superior to that of descendant management.

However, as shown in Table 5, the founding family is the largest shareholder in many founder management firms. In contrast, descendant management firms often have large shareholders other than the founding family. This fact could cause the differences in performance. Hence, we make use of interaction terms between the generation of senior managers and family firm types (family firm $(M \& O)$, family firm $(O)$, and family firm (M)). In column (2), we use the terms, founder firm $(M \& O)$, founder firm $(M)$, descendant firm $(M \& O)$ and descendant firm $(M)$ as independent variables.

The results of this empirical analysis show that active founders contribute to firm value regardless of the family ownership level, but after the founder retires, the 
performance of family firms both owned and managed by the founder's descendants is inferior to that of nonfamily firms and other types of family firms. ${ }^{20}$

The coefficients on both founder firm (M\&O) and founder firm $(M)$ are positive and significant, and the Wald test in the lower panel shows that the difference between the effect of founder firm $(M \& O)$ and that of descendant firm $(M \& O)$, and between the effect of founder firm (M) and that of descendant firm (M) are both significant at conventional level. This result confirms previous findings that shareholders pay a premium for the founder's presence (Fahlenbrach, 2004; Adams et al., 2004).

The coefficient on descendant firm (M\&O) is negative and significant at $5 \%$ level, and the wald test shows that the difference between the effect of descendant firm $(M \& O)$ and that of descendant firm (M) is statistically significant at the $1 \%$ level. In contrast, difference between the effect of founder firm $(M \& O)$ and that of founder firm $(M)$ is not significant. This result shows that the valuation of the firm managed by founder is not affected by corporate governance problems between large founding family shareholders and small shareholders. But after the founder retires, this problem rises to the surface, and degrades the valuation of the family firms both owned and managed by the founder's descendants. ${ }^{21}$

${ }^{20}$ When we use return on assets (ROA) as the dependent variable, the results are quantitatively similar except the effects of descendant firm $(M \& O)$, which become positive but not significant. This difference was probably caused by the fact that Tobin's $q$ reflects what management will accomplish, whereas ROA reflects what management has accomplished. The second difference between Tobin's $q$ and ROA lies in who is actually measuring performance. ROA is measured by accountants constrained by standards set by their profession, whereas Tobin's $q$ is determined by the community of investors constrained by their acumen, optimism, or pessimism. Therefore, our research may indicate that even though descendant firm $(M \& O)$ is an effective organizational structure at present, investors predict that this advantage will eventually vanish because of the corporate governance problem.

21 Nonfamily firms include many firms that were founded by domestic companies, foreign companies, or government, or spun off from a parent company. These firms do not have a founder or founding families. In our sample, 777 of the 1,818 firms do not have a founder and founding family. In order to compare the performance of family-succession firms with that of nonsuccession firms that have broken off relations with their founding families due to hiring of nonfamily professional managers or selling out their shares, we exclude the firms which do not have founder and founding family from the full sample, and estimate the effect of descendant firms on Tobin's q. Similarly, we find that the performance of family firms both owned and managed by the founder's 
In column (3), we add descendant-in-law firm (M\&O) and descendant-in-law firm $(M)$ to the independent variables. In other words, the coefficients on descendant-in-law firm $(M \& O)$ and descendant-in-law firm $(M)$ show differences in the effect of descendant-in-blood management and descendant-in-law management. The result is very interesting. Contrary to our prediction, the coefficients of descendant-in-law firm $(M \& O)$ and descendant-in-law firm $(M)$ are both negative and significant, suggesting that the performance of family firms managed by descendant-in-law is inferior to that of family firms managed by descendant-in-blood. These results might indicate that descendant-in-law senior managers tend to create the situation of dual power between him and founding family, especially his wife's father. This dual power might delay the decision-making process and cause inefficiency of management. As a result, family firms managed by descendant-in-law senior managers are devalued by investors.

In column (4), we add 3rd generation firm (M\&O) and 3rd generation firm (M) to the independent variables in column (2) to analyze the effects of different generations of the founder's descendants on firm performance. The coefficients of 3rd generation firm ( $M \& O)$ and 3rd generation firm (M) indicate the difference in the effect between 2nd generation management and 3rd generation management. However, we could not find significant differences between 2nd generation management and 3rd generation management.

\section{Robustness Test}

\section{5-1. Alternative Definitions}

In this section, we analyze the sensitivity of our main result (column (2) in Table 9) to the use of alternative definitions of family firm and econometric techniques.

Throughout the paper, we assume that the firms are managed by their founding families, when the founder or his descendant is the president or chairman and that firms are owned by their founding families, when the founding family is the largest shareholder. In this section, we use alternative definitions in order to analyze the sensitivity of our main result.

descendants is inferior to that of nonsuccession firms. 
Previous studies in the US, Anderson and Reeb (2003) and Villalonga and Amit (2006) have less stringent requirements for family ownership. They define family firms as firms where the founder or a member of the founding family is an officer, director, or the owner of at least 5\% of the firm's equity. Based on this, we define family firms as firms where the founder or a member of the founding family is the chairman, president, or owner of at least $5 \%$ of the firm's equity rather than the largest shareholder. ${ }^{22}$ However, the use of this alternative definition of family firm does not change our results. By adopting this definition, firms in which the founding family owns $5 \%$ or more of the firm's equity, but is not the largest shareholder, and the founding family members are not president or chairman have newly been included in the category of family firm. However, this type of firms constitutes only 4\% (30 firms) of alternative family firms $(727=697+30$ firms $)$. Column (1) in Table 10 shows the results when we use an alternative classification rule with regard to family ownership. We classify the family firms into family firm (M\&O), family firm (M) and family firm (O), based on whether the founding family is the owner of at least $5 \%$ of the firm's equity rather than the largest shareholder. In other words, family firm (M\&O) is a firm where the senior manager (president or chairman) is either the founder or his descendant, and the founding family owns 5\% or more of the firm's equity. Family firm (M) is a firm where the senior manager is either the founder or his descendant, but the founding family owns less than $5 \%$ of the firm's equity. Family firm $(O)$ is a firm where the founding family owns $5 \%$ or more of the firm's equity, but the senior manager is not a family member. Based on this alternative classification rule, we obtain an alternative family firm (O), founder firm (M\&O), founder firm $(M)$, descendant firm (M\&O) and descendant firm (M). However, when we use these alternative family firms as independent variables, the result of the OLS regression is quantitatively similar to our main result.

Column (2) in Table 10 show the results when we use an alternative definition of senior manager. We define family management as those firms in which the founder or

\footnotetext{
${ }^{22}$ We are unable to identify the family director (although we are able to identify the president, chairman, and representative directors), because reliable sources of the data for them are unavailable.
} 
his descendant is the representative director ${ }^{23}$ rather than the president or chairman. In 1990, it was found that 22 founders were not president and chairman but representative directors, and 9 founders were not representative directors but chairmen. Based on this alternative definition, we obtain an alternative family firm $(O)$, founder firm $(M \& O)$, founder firm (M), descendant firm (M\&O) and descendant firm (M). The result of the OLS regressions is almost the same as that of the previous results; however, founder firm $(M)$ has a larger and more significant positive effect. In sum, our main result is robust to using these alternative definitions of family ownership and management.

\section{5-2. Alternative Econometric Techniques}

Columns (3)-(5) in Table 10 analyze the sensitivity of our main result to the use of alternative econometric techniques.

In the previous regressions presented in Tables 8 and 9, we exclude from the sample the firms with a Tobin's $q$ below the 1st percentile and above the 99th percentile in order to address the difficulties associated with outliers in the data. In this section, we also estimate the same regression model, using the least absolute deviation criterion (instead of least squares deviation criterion) with respect to departures from the median. Column (3) in Table 10 shows the results of the median regression. The result is almost the same as the OLS result.

Our data consists of a cross-sectional time-series panel. In the main tests, we control for lack of independence among observations from the same firm by estimating robust OLS regressions with clusters based on firms. An alternative test procedure is to use a random effects and fixed effects model. Panel regression allows us to take into account the unobserved and time-invariant heterogeneity of our firms. When we use the random

${ }^{23}$ Article 362 of the Commercial Code in Japan stipulates that "the company shall appoint by the resolution of the board of directors, the particular director who shall represent the company." Representative directors have the authority to represent the company in taking external actions and are entrusted with daily executions. Our sample firms have 2.4 representative directors per firm. Itochu Corporation had 28 representative directors in 1991, which is the maximum number of representative directors in our sample. When we use the ratio of family representative directors (= the number of family representative directors/number of representative directors) as independent variables, the coefficient is positive, but not significant. 
effects model, the result is qualitatively identical to the OLS result in Table 9. However, when we use the fixed effects model, the result is considerably different from the previous OLS result. The effect of the active founder is strongly positive in OLS regressions but is insignificant in fixed effects regression. This difference is expected since the fixed effects coefficients are only identified from within-firm changes from a family firm category to another family or nonfamily firm category. In family firms, the management positions are frequently inherited by the founding family members. A good example of this would be that when a founder resigns from a senior manager's position, the founder's descendant becomes the new senior manager. In this case, descendant firm $(M \& O)$ dummy variable changes from 0 to 1 at the same time as founder firm $(M \& O)$ dummy variable changes from 1 to 0 . In our sample, there are 93 cases of management succession from the founder to his descendant; however, there are only 40 cases of management succession from the founder to a nonfamily member. In other words, founder firm (M\&O) and descendant firm (M\&O), and founder firm $(M)$ and descendant firm $(M)$ are strongly correlated with each other in the fixed effects model. When we exclude descendant firm (M\&O) and descendant firm $(M)$ from the set of independent variables, the coefficients of founder firm (M\&O) and founder firm $(M)$ become positive and significant.

An alternative method for controlling the time-invariant differences in firms' characteristics is to compare firm performance before and after each transition of family firms. Table 11 shows the performance changes around each transition of family firms caused by the succession of family senior managers. To prevent results from capturing time or differential industry trends, we estimate the change in industry-adjusted Tobin's $q$. We define change in industry-adjusted Tobin's $q$ as industry-adjusted Tobin's $q$ at two years after transition minus industry-adjusted Tobin's $q$ at two years before transition. Industry-adjusted Tobin's $q$ is defined as Tobin's $q$ minus industry median Tobin's $q$.

Transitions of family firms mainly occur at time of successions of family senior managers. When the founder resigns from the senior manager's position and the founder's descendants become the new senior managers, founder firm (M\&O) is transited to descendant firm $(M \& O)$, or founder firm $(M)$ is transited to descendant firm $(M)$. However, when the founders resigns from the senior manager's position and 
nonfamily members become the new senior managers, founder firm (M\&O) is transited to family firm $(O)$, or founder firm $(M)$ is transited to nonfamily firm. Likewise, 2nd generation firm $(M \& O)$ is transited to 3rd generation firm $(M \& O)$ or family firm $(O)$, and 2nd generation firm (M) is transited to 3rd generation firm (M) or nonfamily firm. ${ }^{24}$

When founder firm $(M \& O)$ is transited to descendant firm $(M \& O)$, we find that industry-adjusted Tobin's $q$ falls by 0.11 on average, significant at the five-percent level. In contrast, when founder firm $(M \& O)$ is transited to family firm $(O)$, industry-adjusted Tobin's $q$ rises by 0.16 , but insignificantly. In addition, the difference in performance change between the transition from founder firm (M\&O) to descendant firm (M\&O) and to family firm $(O)$ is significant at the five-percent level. The results of the median changes exhibit a similar pattern. These results are consistent with Perez-Gonzalez (2006), Bennedsen et al. (2007) and our previous finding that family firms managed by descendant senior managers are devalued by investors. However, we could not find significant results for other transitions. This lack of significance is expected because the number of transitions is likely to be too small.

\section{5-3. Endogeneity Problem}

Many founding families are in a position to determine the structure of management and the ownership levels of family firms. For example, when founders or their descendants retire from management positions, they could choose between leaving their management positions to their descendants or hiring nonfamily professional managers. Founding families could also sell out their equity stake to a third party.

Figure 1 illustrates the transition of family firms in our sample period. This figure indicates that family firms often make the important decisions that change the structure of ownership and management of family firms. For example, 45 firms of 197 founder firms (M\&O) in 1990 do not belong to the founder firm (M\&O) category after four years, and 91 firms do not belong to founder firm (M\&O) after eight years (not shown in Figure 1). In 24 firms of 197 founder firm (M\&O) in 1990, founders retired from management positions, and their descendants, mostly their sons, succeeded within four

${ }^{24}$ The number of all other transition cases caused by the succession of family senior managers is less than two. 
years. In contrast, after the founders retired, nonfamily members assumed the management position in 14 founder firms (M\&O). Focusing on family ownership, the founding family was the largest shareholder in 461 firms in 1990, but in 55 of 461 firms, the founding family stepped down from the largest shareholder position after eight years.

If these changes are determined by firm performance or characteristics, our previous analyses potentially suffer from an endogeneity problem. ${ }^{25}$ In particular, founding families may have superior information and foresight about the firm because they have large equity stakes, senior management positions, and long-term relationships with the firm. Therefore, founding families may have incentives to reduce their equity stakes or step down from management positions when information asymmetries suggest to them that the firm's prospects have diminished. In fact, Smith and Amoako-Adu (1999) show that nonfamily member appointments to senior manager positions tend to follow a period of poor performance.

We tackle this issue using a treatment effects model that estimates jointly the probability of being a family firm, and an outcome equation for market valuation (Maddala, 1983; Heckman et al., 1997; Green, 2000; Wooldridge, 2002). We adopt a maximum likelihood procedure and standard errors are clustered by firm level. This method is more efficient than the traditional two-stage method. The treatment group is a dummy that equals one for family firms as a whole or for one of the five types of family firms. The outcome variable is Tobin's $q$. Sample firms are comprised of only the family firm in the category analyzed and nonfamily firms because we can use only one treatment variable in each estimation.

To meet the exclusion restrictions necessary for identification, we use number of negative profit as the exogenous variable in the treatment equation model. Number of negative profit is the number of times before-tax after-interest profit is negative after an

${ }^{25}$ Several previous studies argue that the ownership structure varies systematically in a way that is consistent with value maximization. Demsetz and Lehn (1985) and Demsetz and Villalonga (2001) show that the ownership structure is determined by firm size, profit variability and government regulation. Himmelberg et al. (1999) show that managerial ownership is determined endogenously. 
IPO. ${ }^{26}$ We use number of negative profit as a long-term firm performance measure. The correlation between Tobin's $q$ and number of negative profit is 0.001 , which is not significantly different from zero. In addition, we use idiosyncratic risk as an exogenous variable. According to the Capital Asset Pricing Model, Tobin's $q$ is a function of market risk (beta), but not of idiosyncratic risk, because idiosyncratic risk can be eliminated by holding a well-diversified portfolio. However, founding families should care about both types of risk because their wealth tends to be concentrated in the equity of the "family firm". The treatment equation model also includes industry-adjusted Tobin's $q$ to test for potential reverse causation. Other variables in the treatment equation are natural log of assets, leverage, beta, and natural log of firm age since the IPO. In the outcome equation model, we use leverage, natural log of firm age since foundation, beta, related firm 1 dummy, related firm 2 dummy, affiliated firm dummy, industry dummies, and year dummies.

In Table 12, we summarize the results obtained from the estimation of the treatment effects model for Tobin's q. The upper panel includes the results from the outcome equation and the lower panel contains the estimates for the treatment equation. The treatment equation results confirm that family ownership and management are themselves a function of prior performance. The coefficients of industry-adjusted Tobin's $q$ are positive and significant for the family firm as whole, including both founder firms and descendant management-only family firms. However, the same coefficient is negative and significant for descendant firm (M\&O). Number of negative profit has negative effects for all types of family firms. The coefficient on log of assets is negative and significant for descendant firm (M\&O). This result may indicate that descendant firms ( $M \& O$ ) have not chosen to issue new equity, to prevent the dilution of family ownership.

The results of the outcome equations strongly confirm the robustness of our findings in the OLS regressions. The effect of descendant firm (M\&O) is negative and significant at the $1 \%$ level. The effect of descendant firm $(M)$ is positive and significant at the $1 \%$ level, although these effects are not significant in the OLS regressions. These

${ }^{26}$ Due to data constraints, only profit data after 1956 is used for firms listed before 1955. 
results may suggest that descendant senior manager have a family-specific ability and an incentive transferred between generations. However, this benefit might by offset by less competitive succession and the probability of expropriation from small shareholders, when founding family is the largest shareholder.

\section{Summary and Conclusion}

We have investigated the relationship between family firms and firm value. Family firms are different from the well-known "Berle and Means firm”, where ownership is dispersed among small shareholders, but control is concentrated in the hands of professional managers. In addition, family firms are prevalent around the world. However, they have received relatively little attention. Using data from 1,818 publicly traded firms in Japan from 1990 to 1998, we construct a new dataset on founding families, which includes founding family ownership, family management, and generation of family senior managers. We find that founding families are a prevalent and important class of shareholders and senior managers in Japan. Family firms constitute about $38 \%$ of our sample firms. In addition, we find that after the founder retires, family ownership is dispersed and the corporate governance of family firms is transformed. In half of family firms, ownership and management are separated after the founder retires.

We empirically find that family firms slightly outperform nonfamily firms in Japan. However, the family firm premium has mainly arisen from active founders. After founders retire, the results are mixed. We find that the performance of family firms both owned and managed by the founder's descendants is inferior to that of nonfamily firms, but the performance of family firms owned or managed by the founder's descendants is superior to that of nonfamily firms. These results may indicate that founders add firm value through their valuable skills, and a poor performance of descendant firms is mainly the result of governance problems between large and small shareholders. However, as is often observed with identified correlations between governance structure and firm value, simultaneity issues complicate the interpretation of our findings. We can propose some other interpretations that involve a selection effect rather than such a causal link. For example, founders do not resign from senior management positions of 
well-performing firms, or nonfamily members do not take over the management of poorly performing firms from founding family members. To address these endogeneity problems, we use the treatment effects model that jointly estimates the probability of being a family firm and an outcome equation for market valuation, and confirm the robustness of our findings in the OLS regressions. However, we might have failed to fully address the simultaneity issue because we may have made very strong identification assumptions that number of negative profit and idiosyncratic risk affect the decision of family firms, but not firm value.

Furthermore, we find that contrary to the general view that recruiting a capable man through marriage mitigates the inherent cost of restricted executive pool in founding family, investors devalue family firms managed by descendants-in-law compared with family firms managed by descendants-in-blood.

Our results raise new and important research questions of how these founding families affect the behavior of the firm, for example, their investment and payout policy. Because the performance of family firms is different from that of nonfamily firms, we can predict that the founding family affects the behavior of the firm. Therefore, more effort is needed for developing a better understanding of family firms. 


\section{Appendix: Family Ownership and Management Data}

Since comprehensive data sources on the ownership and management of founding families are not available in Japan, we manually collect data from several sources, for the period 1990 through 1998, for 1,818 sample firms.

For this purpose, we first identify the founders and founding families of all 1,818 sample firms, using the Firm History Book (published by Toyo Keizai Shinposya). The Firm History Book presents the history of 3,072 Japanese firms, which include all the listed firms in 1995. In instances where we are unable to identify the founder and founding family from the Firm History Book, we use Yuka Syoken Hokokusyo and Nikkei Telecom 21. ${ }^{27}$ If we are still unable to identify the founder and founding family, we label these firms as nonfounder firms, which include firms founded by other companies or the government, and spin-off from the parent companies. When there is more than one founder, we consider the founding family to be the family with the largest share holding. For example, Sony was founded by Akio Morita and Masaru Ibuka. In 1990, although the Morita family owned 6.4\% of the shareholding, the Ibuka family was not included among the twenty largest shareholders. Therefore, we consider the Morita family as the founding family of Sony.

Next, we obtain family ownership data for all the sample years. Family ownership is the percentage of shares held by the founding family as a group. To collect family ownership data, we refer to the annual editions of Kigyo Keiretsu Soran (published by Toyo Keizai Shinposya), which includes a list of the twenty largest shareholders of each firm. In instances where no shareholder in this list is related to the founding family, family ownership is considered to be zero. On the other hand, in instances where more than one shareholder is related to the founding family, family ownership is considered to be an aggregation of these. However, there is great difficulty in determining actual family ownership. Many founding families have a holding company or foundation. ${ }^{28}$

27 Yuka Syoken Houkousyo corresponds with 10-K filings in the US. Nikkei Telecom 21 is an electric newspaper archive, which includes the Nikkei, Nikkei Business Daily, Nikkei Marketing Journal and Nikkei Financial Daily.

${ }^{28}$ In Japan, many founding families establish holding companies in order to preserve their assets. The use of holding companies instead of direct holdings has many tax benefits (especially in cases involving inheritance). Most of the holding companies are 
For instance, in the case of Sony, in the 1990s, Akio Morita and his family were not included in the list of largest shareholders. However, Reikei, which is the Morita family's holding company, owned $5.4 \%$ of the shareholdings and was the largest shareholder of Sony. To identify these companies and foundations, we refer to Dai Kabunushi Soran (published by Toyo Keizai Shinposya), which provides the background of large shareholders. Dai Kabunushi Soran identifies the holding company and foundation of the founding family, based on the substantial shareholding report submitted to the Ministry of Finance. In Japan, the substantial shareholding report system requires a person or entity to file the same if it becomes a beneficial holder of more than $5 \%$ of the shares of a listed firm. This shareholding is defined as an aggregate of the shareholdings of associated companies and parties that have entered into a concerted agreement with the purchaser. For example, if the founder owns $3 \%$ of the shareholdings and his holding company owns 5\% of the firm's equity, the founder or his holding company has to prepare a report stating that they owns $8 \%$ of the firm's equity.

Finally, we construct family management data for all the sample years. The information on the companies' senior managers (chairman, president and other representative directors) is sourced from the annual editions of Yakuin Shikiho (published by Toyo Keizai Shinposya), which provides the names and titles of all the directors of public companies in Japan. We investigate the blood and affinity relations between the founder and all senior managers for the sample years by referring to Nikkei Telecom 21. The Nikkei and Nikkei Business Daily report the backgrounds of new presidents including information such as whether they are members of the founding family and are related to the founder or previous president. In instances where the chairmen or other representative directors have never been president, we search for other articles that provide information on their backgrounds by using the relevant name as the keyword. In addition, we use the Directory of Directors in 1983 (published by Zaikai Kenkyusyo). This directory lists the names and relations of the directors' family members. However, we are unable to use this directory as the main data source since it

privately held companies. We assume that founding families hold $100 \%$ of their holding companies' equity. 
is slightly outdated and does not include data of all the directors. Therefore, we use this directory to verify and complement our family management data. 


\section{References}

Adams, R., Almeida, H., and Ferreira, D., 2004, Understanding the Relationship between Founder-CEOs and Firm Performance, Working Paper, New York University.

Anderson, R., and Reeb, D., 2003, Founding Family Ownership and Performance. Evidence from the S\&P 500. Journal of Finance 58, 1301-1327.

Anderson, R., Mansi, S., and Reeb, D., 2003, Founding Family Ownership and the Agency Costs of Debt, Journal of Financial Economics 68, 263-285.

Bennedsen, M., Nielsen, K., Perez-Gonzalez, F., and Wolfenzon, D., 2007, Inside the Family Firm: the Role of Families in Succession Decisions and Performance, Quarterly Journal of Economics 122, 647-691.

Barth, E., Gulbrandsen, T., and Schonea, P., 2005, Family Ownership and Productivity: the Role of Owner-management, Journal of Corporate Finance 11, 107-127.

Berle, A., and Means, G., 1932, The Modern Corporation and Private Property, New York: Macmillan.

Bertland, M., and Schoar, A., 2006, The Role of Family in Family Firms, Journal of Economic Perspectives 20, 73-96.

Bertland, M., Johnson, S., Samphantharak, K., and Schoar, A., 2005, Mixing Family With Business: A Study of Thai Business Groups and the Families Behind Them, Working Paper, University of Chicago.

Bloom, N., and Van Reenen, J., 2007, Measuring and Explaining Management Practices across Firms and Countries, Quarterly Journal of Economics 122, 1351-1408.

Burkart, M., Panunzi, F., and Shleifer, A., 2003, Family Firms. Journal of Finance 58, 2167-2202.

Claessens, S., Djankov, S., and Lang, L. P. H., 2000, The Separation of Ownership and Control in East Asian Corporations, Journal of Financial Economics 58, 81-112.

Claessens, S., Djankov, S., Fan, J., and Lang, L., 2002, Disentangling the Incentives and Entrenchment Effects of Large Shareholdings, Journal of Finance 57, 2741-2471. 
Cronqvist, H., and Nilsson, M., 2003, Agency Costs of Controlling Minority Shareholders, Journal of Financial and Quantitative Analysis 38, 695-719.

Davis, J., Schoorman, D., and Donaldson, L., 1997, Toward a Stewardship Theory of Management, Academy of Management Review 22, 20-47.

Demsetz, H., and Lehn, K., 1985, The Structure of Corporate Ownership: Causes and Consequences, Journal of Political Economy 93, 1155-1177.

Demsetz, H., and Villalonga, B., 2001, Ownership Structure and Corporate Performance, Journal of Corporate Finance 7, 209-233.

Dunn, T., and Holtz-Eakin, D., 2000, Financial Capital, Human Capital, and the Transition to Self-Employment: Evidence from Intergenerational Links, Journal of Labor Economics 18, 282-305.

Dyck, A., and Zingales, L., 2004, Private Benefits of Control: An International Comparison, Journal of Finance 59, 537-600.

Faccio, M., and Lang, L., 2002, The Ultimate Ownership of Western European Corporations, Journal of Financial Economics 65, 365-395.

Fahlenbrach, R., 2004, Founder-CEOs and Stock Market Performance, Working Paper, Wharton School, University of Pennsylvania.

Green, W. H., 2000, Econometric Analysis, New Jersey: Pearson Education, Inc.

Heckman, J., Ichimura, H., and Todd, P., 1997, Matching as an Econometric Evaluation Estimator: Evidence from Evaluating a Job Training Programme, Review of Economic Studies 64, 605-654.

Himmelberg, C., Hubbard, G., and Palia, D., 1999, Understanding the Determinants of Managerial Ownership and the Link Between Ownership and Performance, Journal of Financial Economics 53, 353-384.

Hori, K., Saito, M., and Ando, K., 2006, What Caused Fixed Investment to Stagnate during the 1990s in Japan?: Evidence from Panel Data of Listed Companies, Japanese Economic Review 57, 283-306.

Jensen, M., and Mechling, W., 1976, Theory of the Firm: Managerial Behavior, Agency Costs, and Ownership Structure, Journal of Financial Economics 3, 305-360.

Laband, D., and Lentz, B., 1986, Like Father, Like Son: Toward an Economic Theory of Occupational Following, Southern Economic Journal 50, 474-493. 
La Porta, R., Lopez-de-Silanes, F., and Shleifer, A., 1999, Corporate Ownership Around the World, Journal of Finance 54, 471-517.

Leland, H., and Pyle, D., 1977, Informational Asymmetries, Financial Structure, and Financial Intermediation, Journal of Finance 32, 371-387.

Lentz, B., and Laband, D., 1990, Entrepreneurial Success and Occupational Inheritance among Proprietors, Canadian Journal of Economics 23, 563-579.

Maddala, G., 1983, Limited-dependent and Qualitative Variables in Econometrics, Cambridge: Cambridge University Press.

Maury, B., 2006, Family Ownership and Firm Performance: Empirical Evidence from Western European Corporations, Journal of Corporate Finance 12, 321-341.

McConnaughy, D., Walker, M., Henderson, G., and Chandra, M., 1998, Founding Family Controlled Firms: Efficiency and Value, Review of Financial Economics 7, 1-19.

Miyajima, H., Arikawa, Y., and Saito, N., 2001, On Japanese Corporate Governance: A Comparative Study of the Oil Shock Period and the Bubble Period, Financial Review 60, 139-168. (in Japanese)

Morck, R., Shleifer, A., and Vishny, R., 1988, Management Ownership and Market Valuation: An Empirical Analysis, Journal of Financial Economics 20, 293-315.

Morck, R., Strangeland, D., and Yeung, B., 2000, Inherited Wealth, Corporate Control, and Economic Growth, in Morck, R., ed: Concentrated Corporate Ownership (University of Chicago Press, Chicago).

Perez-Gonzalez, F., 2006, Inherited Control and Firm Performance, American Economic Review 96, 1559-1588.

Prowse, S., 1992, The Structure of Corporate Ownership in Japan, Journal of Finance 47, 1121-1140.

Shleifer, A., and Vishny, R., 1986, Large Shareholders and Corporate Control, Journal of Political Economy 94, 461-488.

Shleifer, A., and Vishny, R., 1997, A Survey of Corporate Governance, Journal of Finance 52, 737-783.

Smith, B., and Amoako-Adu, B., 1999, Management Succession and Financial 
Performance of Family Controlled Firms, Journal of Corporate Finance 5, 341-368.

Sraer, D., and Thesmar, D., 2007, Performance and Behavior of Family Firms: Evidence from the French Stock Market, Journal of the European Economic Association 5, 709-751.

Villalonga, B., and Amit, R., 2006, How Do Family Ownership, Control and Management Affect Firm Value?, Journal of Financial Economics 80, 385-417.

Wooldridge, J., 2002, Econometric Analysis of Cross Section and Panel Data, Cambridge: MIT Press. 


\section{Table 1. Variable Definitions}

\begin{tabular}{|c|c|}
\hline Variable & Defnitions \\
\hline \multicolumn{2}{|l|}{ Family firm variables } \\
\hline Family firm & $\begin{array}{l}\text { Equals one if founder or his descendant is a president or chairman and/or founding } \\
\text { family is the largest shareholder of the firm. }\end{array}$ \\
\hline Family ownership & Ratio of shares held by founding family as a group to total shares. \\
\hline Family management & Equals one if founder or his descendant is a president or chairman. \\
\hline Family firm (M\&O) & $\begin{array}{l}\text { Equals one if founder or his descendant is a president or chairman and founding family is } \\
\text { the largest shareholder of the firm. }\end{array}$ \\
\hline Family firm (M) & $\begin{array}{l}\text { Equals one if founder or his descendant is a president or chairman, but founding family is } \\
\text { not the largest shareholder of the firm. }\end{array}$ \\
\hline Family firm (O) & $\begin{array}{l}\text { Equals one if founding family is the largest shareholder of the firm, but senior manager is } \\
\text { nonfamily member. }\end{array}$ \\
\hline Founder management & Equals one if founder is a president or chairman. \\
\hline Descendant management & Equals one if founder's descendant is a president or chairman after founder retired. \\
\hline 2nd generation management & $\begin{array}{l}\text { Equals one if 2nd generation founding family member is a president or chairman after } \\
\text { founder retired. }\end{array}$ \\
\hline 3rd generation management & $\begin{array}{l}\text { Equals one if 3rd generation founding famly member is a president or chairman after } \\
\text { founder and 2nd generation founding family member retired. }\end{array}$ \\
\hline Descendant-in-law management & $\begin{array}{l}\text { Equals one if in-law founding family member is a president or chairman after founder } \\
\text { retired. }\end{array}$ \\
\hline Family representative director & The number of representative directors from founding family. \\
\hline Family representative director ratio & Number of family representative directors/number of representative directors. (\%) \\
\hline \multicolumn{2}{|l|}{ Performance variables } \\
\hline Tobin's q & Book value of leverage plus market value of shares divided by market value of assets. \\
\hline Industry-adjusted Tobin's q & Tobin's $q$ minus industry median Tobin's $q$. \\
\hline ROA & Ratio of operating income before tax and interests to market value of assets. (\%) \\
\hline Industry-adjusted ROA & ROA minus industry median ROA. \\
\hline Number of negative profit & $\begin{array}{l}\text { Number of the times when before-tax after-interest profit is negative after IPO. Due to } \\
\text { data constraint, we use the profit data after } 1956 \text { for the firm listed before } 1955 \text {. }\end{array}$ \\
\hline \multicolumn{2}{|l|}{ Control variables } \\
\hline Assets & $\begin{array}{l}\text { Book value of assets minus book value of tangible asssets plus market value of tangible } \\
\text { assets. }\end{array}$ \\
\hline Leverage & Ratio of the sum of short-term debt and long-term debt to total assets. (\%) \\
\hline Beta & $\begin{array}{l}\text { Estimate from market model in which the firm's monthly stock returns over the } 60 \\
\text { months are regressed on the TOPIX monthly returns. }\end{array}$ \\
\hline Idiosyncratic risk & $\begin{array}{l}\text { Standard deviation of residuals from market model in which the firm's monthly stock } \\
\text { returns over the } 60 \text { months are regressed on the TOPIX monthly returns. }\end{array}$ \\
\hline Related firm 1 & Equals one if largest shareholder other than founding family has 15\%-33.3\% shares. \\
\hline Related firm 2 & Equals one if largest shareholder other than founding family has 33.4\%-50\% shares. \\
\hline Affiliated firm & Equals one if largest shareholder other than founding family has over $50 \%$ shares. \\
\hline
\end{tabular}

Notes: This table shows the definitions of the variables used in the analyses. Detailed explanations on the construction of family ownership and management data are in Appendix. Performance variables and control variables except beta and idiosyncratic risk are obtained from the Corporate Financial Databank, compiled by the Development Bank of Japan. Beta and idiosyncratic risk is calculated using the Kabuka CD-ROM (published by Toyo Keizai Shinposya). 
Table 2. Prevalence of Founding Family in Japanese Publicly Traded Firms

\begin{tabular}{lccc}
\hline \hline & \multicolumn{2}{c}{ Family management } & \\
\cline { 2 - 3 } Family ownership & $\begin{array}{c}\text { Senior manager not } \\
\text { from founding family }\end{array}$ & $\begin{array}{c}\text { Senior manager from } \\
\text { founding family }\end{array}$ & Sum \\
\hline Family ownership $=0$ & 1034 & 46 & 1080 \\
$0<$ Family ownership $<5$ & 57 & 131 & 188 \\
$5<=$ Family ownership $<10$ & 30 & 125 & 155 \\
$10<=$ Family ownership $<20$ & 26 & 173 & 199 \\
$20<=$ Family ownership & 12 & 184 & 196 \\
\hline Sum & 1159 & 659 & 1818 \\
\hline Family is largest shareholder & 38 & 423 & 461 \\
\hline \hline
\end{tabular}

Notes: This table shows the prevalence of founding family in Japanese publicly traded firms in 1990. The sample consists of the firms listed on the First and Second Sections of the Stock Exchanges of Tokyo, Osaka, and Nagoya at the end of 1990, with financial firms and public utility firms excluded. Family ownership is the percentage of shares held by the founding family as a group. Senior manager indicates president and chairman. Detailed explanations on the construction of family ownership and management data are in Appendix. 
Table 3. Number and Percent of Family and Nonfamily Firms

\begin{tabular}{|c|c|c|c|c|c|c|}
\hline \multirow[b]{2}{*}{ Industry description } & \multirow[b]{2}{*}{$\begin{array}{l}\text { Nonfamily } \\
\text { firms }\end{array}$} & \multicolumn{4}{|c|}{ Family firm } & \multirow[b]{2}{*}{$\begin{array}{l}\text { Percent family } \\
\text { firms in industry }\end{array}$} \\
\hline & & $\begin{array}{l}\text { Family firm } \\
\text { (M\&O) }\end{array}$ & $\begin{array}{l}\text { Family firm } \\
\text { (M) }\end{array}$ & $\begin{array}{l}\text { Family fim } \\
\text { (O) }\end{array}$ & Sum & \\
\hline Foods & 57 & 27 & 16 & 4 & 47 & 45.19 \\
\hline Textiles \& apparel & 55 & 7 & 10 & 0 & 17 & 23.61 \\
\hline Lumber \& wood & 2 & 4 & 0 & 0 & 4 & 66.67 \\
\hline Paper \& pulp & 22 & 8 & 2 & 0 & 10 & 31.25 \\
\hline Publishing \& printing & 5 & 6 & 1 & 0 & 7 & 58.33 \\
\hline Chemicals & 107 & 24 & 25 & 4 & 53 & 33.13 \\
\hline Oil \& coal & 7 & 0 & 1 & 0 & 1 & 12.50 \\
\hline Rubber & 11 & 5 & 2 & 0 & 7 & 38.89 \\
\hline Glass \& ceramics & 45 & 9 & 11 & 0 & 20 & 30.77 \\
\hline Iron \& steel & 43 & 9 & 3 & 1 & 13 & 23.21 \\
\hline Nonferrous metals & 33 & 4 & 3 & 0 & 7 & 17.50 \\
\hline Metal products & 33 & 19 & 8 & 1 & 28 & 45.90 \\
\hline General machinery & 108 & 37 & 33 & 4 & 74 & 40.66 \\
\hline Electric applicances & 100 & 32 & 27 & 8 & 67 & 40.12 \\
\hline Transportation equipment & 82 & 14 & 19 & 0 & 33 & 28.70 \\
\hline Precision instruments & 19 & 6 & 8 & 1 & 15 & 44.12 \\
\hline Other products & 28 & 21 & 9 & 0 & 30 & 51.72 \\
\hline Fishery & 2 & 0 & 0 & 0 & 0 & 0.00 \\
\hline Mining & 8 & 0 & 0 & 0 & 0 & 0.00 \\
\hline Construction & 39 & 35 & 12 & 3 & 50 & 56.18 \\
\hline Dredging & 3 & 2 & 0 & 0 & 2 & 40.00 \\
\hline Other construction & 43 & 4 & 1 & 0 & 5 & 10.42 \\
\hline Wholesale trade & 69 & 55 & 16 & 6 & 77 & 52.74 \\
\hline Retail trade & 46 & 61 & 12 & 1 & 74 & 61.67 \\
\hline Real estate & 27 & 5 & 0 & 0 & 5 & 15.63 \\
\hline Railways & 19 & 1 & 2 & 0 & 3 & 13.64 \\
\hline Road passenger transport & 5 & 2 & 1 & 0 & 3 & 37.50 \\
\hline Road freight transport & 8 & 3 & 4 & 0 & 7 & 46.67 \\
\hline Marine transportation & 19 & 1 & 2 & 1 & 4 & 17.39 \\
\hline Air transportation & 4 & 0 & 0 & 0 & 0 & 0.00 \\
\hline Warehousing & 9 & 3 & 1 & 1 & 5 & 35.71 \\
\hline Harbor transportation & 14 & 3 & 2 & 1 & 6 & 30.00 \\
\hline Comunication & 2 & 0 & 0 & 0 & 0 & 0.00 \\
\hline Hotel & 9 & 0 & 0 & 0 & 0 & 0.00 \\
\hline Films \& amusement & 21 & 4 & 3 & 0 & 7 & 25.00 \\
\hline Broadcasting & 4 & 0 & 0 & 0 & 0 & 0.00 \\
\hline Business services & 2 & 1 & 0 & 0 & 1 & 33.33 \\
\hline Information services & 7 & 5 & 0 & 0 & 5 & 41.67 \\
\hline \multirow[t]{2}{*}{ Other services } & 4 & 6 & 2 & 2 & 10 & 71.43 \\
\hline & 1121 & 423 & 236 & 38 & 697 & 38.34 \\
\hline
\end{tabular}

Notes: This table shows the number and percent of family firms and nonfamily firms by two-digit industry in 1990. The industry classification is based on the Corporate Financial Databank, compiled by the Development Bank of Japan. The sample consists of the firms listed on the First and Second Sections of the Stock Exchanges of Tokyo, Osaka, and Nagoya at the end of 1990, with financial firms and public utility firms excluded. Family firm is defined as those in which the founder or his descendant is a president or chairman and/or the founding family is the largest shareholder in the firm. Family firm $(M \& O)$ is a firm where the senior manager (president or chairman) is either the founder or his descendant, and the founding family is the largest shareholder. Family firm (M) is a firm where the senior manager is either the founder or his descendant, but the founding family is not the largest shareholder. Family firm $(O)$ is a firm where the founding family is the largest shareholder, but the senior manager is not a founding family member. 
Table 4. Summary Statistics in 1990

\begin{tabular}{lccccc}
\hline \hline & \multicolumn{5}{c}{ All firms } \\
\cline { 2 - 6 } & Mean & Median & $\begin{array}{c}\text { Standard } \\
\text { deviation }\end{array}$ & Min & Max \\
\hline Number of firms & & & 1818 & & \\
Family ownership (\%) & 5.82 & 0 & 10.65 & 0 & 64.29 \\
Largest shareholder is founding family & 0.25 & 0 & 0.44 & 0 & 1 \\
Family representative director & 0.51 & 0 & 0.51 & 0 & 4 \\
Family Firm & 0.38 & 0 & 0.49 & 0 & 1 \\
Family representative director ratio (\%) & 27.18 & 0 & 40.02 & 0 & 100 \\
Senior manager is from founding family & 0.36 & 0 & 0.48 & 0 & 1 \\
& & & & & \\
Tobin's q & 1.45 & 1.28 & 0.70 & 0.39 & 7.13 \\
Industry-adjusted Tobin's q & 0.11 & -0.02 & 0.65 & -1.44 & 5.71 \\
ROA (\%) & 6.89 & 6.31 & 3.59 & -10.92 & 42.78 \\
Industry-adjusted ROA (\%) & 0.17 & -0.17 & 3.44 & -18.59 & 36.70 \\
& & & & & \\
Assets (billion yen) & 196 & 55 & 625 & 1.80 & 14800 \\
Sales (billion yen) & 204 & 48 & 104 & 0.79 & 18900 \\
Leverage (\%) & 22.05 & 20.66 & 14.98 & 0.00 & 91.38 \\
Beta & 0.98 & 0.99 & 0.40 & -0.61 & 3.59 \\
Idiosyncratic risk & 0.09 & 0.09 & 0.03 & 0.01 & 0.37 \\
Firm age since foundation & 62.86 & 56.00 & 38.20 & 9 & 529 \\
Firm age since IPO & 26.19 & 29.00 & 12.61 & 1 & 41 \\
Ownership by largest shareholder & 16.98 & 8.77 & 15.90 & 1.36 & 72.03 \\
(except founding family) (\%) & 0.19 & 0 & 0.39 & 0 & 1 \\
Related firm 1 & 0.11 & 0 & 0.31 & 0 & 1 \\
Related firm 2 & 0.07 & 0 & 0.26 & 0 & 1 \\
Affiliated firm & & & & &
\end{tabular}

Notes: This table shows the summary statistics in 1990. The sample consists of the firms listed on the First and Second Sections of the Stock Exchanges of Tokyo, Osaka, and Nagoya at the end of 1990, with financial firms and public utility firms excluded. Family ownership is the percentage of shares held by the founding family as a group. Family firm is defined as those in which the founder or his descendant is the senior manager (president or chairman) and/or the founding family is the largest shareholder in the firm. The definitions of other variables are explained at Table 1 . Financial data are obtained from the Corporate Financial Databank, compiled by the Development Bank of Japan. Beta and idiosyncratic risk is calculated using the Kabuka CD-ROM (published by Toyo Keizai Shinposya). 
Table 5. Summary Statistics for Family and Nonfamily Firms

\begin{tabular}{|c|c|c|c|c|c|c|c|c|c|c|c|c|}
\hline & \multicolumn{8}{|c|}{ Family firm type } & \multirow{2}{*}{\multicolumn{2}{|c|}{ Nonfamily firms }} & \multirow{2}{*}{\multicolumn{2}{|c|}{$\begin{array}{l}\text { Family firm vs } \\
\text { nonfamily firm }\end{array}$}} \\
\hline & \multicolumn{2}{|c|}{ Family firm } & \multicolumn{2}{|c|}{ Family firm (M\&O) } & \multicolumn{2}{|c|}{ Family firm (M) } & \multicolumn{2}{|c|}{ Family firm (O) } & & & & \\
\hline & Mean & Median & Mean & Median & Mean & Median & Mean & Median & Mean & Median & t-test & $\begin{array}{c}\text { Wilcoxon } \\
\text { rank-sum } \\
\text { test }\end{array}$ \\
\hline Number of firms & \multicolumn{2}{|c|}{697} & \multicolumn{2}{|c|}{423} & \multicolumn{2}{|c|}{236} & \multicolumn{2}{|c|}{38} & \multicolumn{2}{|c|}{1121} & & \\
\hline Family ownership (\%) & 14.62 & 11.47 & 20.40 & 17.44 & 3.98 & 2.74 & 16.42 & 12.51 & 0.36 & 0.00 & 36.54 & 36.42 \\
\hline Founder management & 0.37 & 0 & 0.47 & 0 & 0.25 & 0 & 0.00 & 0 & 0.00 & 0 & 25.10 & 21.64 \\
\hline Descendant management & 0.58 & 1 & 0.53 & 1 & 0.75 & 1 & 0.00 & 0 & 0.00 & 0 & 39.18 & 28.85 \\
\hline 2nd generation management & 0.42 & 0 & 0.41 & 0 & 0.50 & 1 & 0.00 & 0 & 0.00 & 0 & 28.92 & 23.94 \\
\hline Descendant-in-law management & 0.06 & 0 & 0.06 & 0 & 0.08 & 0 & 0.00 & 0 & 0.00 & 0 & 8.47 & 8.31 \\
\hline Family representative director & 1.30 & 1 & 1.40 & 1 & 1.31 & 1 & 0.08 & 0 & 0.01 & 0 & 62.71 & 38.78 \\
\hline Family representative director ratio (\%) & 70.16 & 100 & 78.81 & 100 & 65.72 & 50 & 3.21 & 0 & 0.04 & 0 & 68.15 & 38.77 \\
\hline Tobin's $q$ & 1.51 & 1.35 & 1.53 & 1.36 & 1.49 & 1.34 & 1.46 & 1.30 & 1.41 & 1.24 & 3.11 & 3.63 \\
\hline Industry-adjusted Tobin's $q$ & 0.16 & 0.02 & 0.18 & 0.04 & 0.14 & 0.00 & 0.07 & -0.03 & 0.07 & -0.06 & 3.15 & 3.73 \\
\hline ROA (\%) & 7.64 & 7.05 & 8.10 & 7.45 & 6.80 & 6.29 & 7.76 & 6.90 & 6.43 & 6.02 & 7.10 & 7.22 \\
\hline Industry-adjusted ROA (\%) & 0.77 & 0.21 & 1.15 & 0.47 & 0.09 & -0.12 & 0.78 & 0.66 & -0.20 & -0.48 & 6.01 & 6.08 \\
\hline Assets (billion yen) & 14.30 & 5.00 & 11.10 & 4.37 & 20.20 & 7.02 & 13.60 & 4.15 & 22.80 & 5.70 & 2.84 & 2.30 \\
\hline Beta & 0.90 & 0.91 & 0.85 & 0.87 & 0.98 & 0.98 & 0.85 & 0.83 & 1.03 & 1.05 & 5.19 & 5.12 \\
\hline Idiosyncratic risk & 0.09 & 0.09 & 0.09 & 0.09 & 0.09 & 0.09 & 0.09 & 0.09 & 0.09 & 0.09 & 0.53 & 0.39 \\
\hline Firm age since foundation & 63.68 & 55.00 & 58.53 & 52.00 & 71.53 & 60.00 & 72.21 & 54.50 & 62.35 & 56.00 & 0.72 & 2.31 \\
\hline Firm age since IPO & 20.72 & 27.00 & 16.57 & 16.00 & 28.28 & 29.00 & 19.97 & 19.00 & 29.58 & 29.00 & 15.51 & 14.96 \\
\hline $\begin{array}{l}\text { Ownership by largest shareholder } \\
\text { (except founding family) (\%) }\end{array}$ & 7.90 & 5.20 & 5.52 & 4.98 & 12.50 & 7.63 & 5.71 & 4.99 & 22.62 & 18.30 & 21.49 & 23.22 \\
\hline Related firm 1 & 0.08 & 0 & 0.01 & 0 & 0.21 & 0 & 0.00 & 0 & 0.26 & 0 & 9.53 & 9.31 \\
\hline Related firm 2 & 0.01 & 0 & 0.00 & 0 & 0.04 & 0 & 0.00 & 0 & 0.16 & 0 & 10.22 & 9.94 \\
\hline Affiliated firm & 0.01 & 0 & 0.00 & 0 & 0.02 & 0 & 0.00 & 0 & 0.11 & 0 & 8.40 & 8.25 \\
\hline
\end{tabular}

Notes: This table shows the summary statistics for family firm, three type family firms and nonfamily firm in 1990. The sample consists of the firms listed on the First and Second Sections of the Stock Exchanges of Tokyo, Osaka, and Nagoya at the end of 1990, with financial firms and public utility firms excluded. The last two columns show the results of t-test and wilcoxon rank-sum test to compare the difference of means and medians between family firms and nonfamily firms. Family firm is defined as those in which the founder or his descendant is a president or chairman and/or the founding family is the largest shareholder in the firm. Family firm (M\&O) is a firm where the senior manager (president or chairman) is either the founder or his descendant, and the founding family is the largest shareholder. Family firm (M) is a firm where the senior manager is either the founder or his descendant, but the founding family is not the largest shareholder. Family firm $(O)$ is a firm where the founding family is the largest shareholder, but the senior manager is not a 
family member.

Table 6. Summary Statistics for Family Firms Clustered by Management Generation

\begin{tabular}{|c|c|c|c|c|c|c|c|c|c|c|}
\hline & \multirow{2}{*}{\multicolumn{2}{|c|}{$\begin{array}{c}\text { Founder } \\
\text { management }\end{array}$}} & \multirow{2}{*}{\multicolumn{2}{|c|}{$\begin{array}{c}\text { Descendant } \\
\text { management }\end{array}$}} & \multicolumn{4}{|c|}{ Descendant management } & \multirow{2}{*}{\multicolumn{2}{|c|}{$\begin{array}{l}\text { Founder management vs } \\
\text { descendant management }\end{array}$}} \\
\hline & & & & & \multicolumn{2}{|c|}{$\begin{array}{c}\text { 2nd generation } \\
\text { management }\end{array}$} & \multicolumn{2}{|c|}{$\begin{array}{c}\text { 3rd generation } \\
\text { management }\end{array}$} & & \\
\hline & Mean & Median & Mean & Median & Mean & Median & Mean & Median & t-test & $\begin{array}{c}\text { Wilcoxon } \\
\text { rank-sum } \\
\text { test }\end{array}$ \\
\hline Number of firms & \multicolumn{2}{|c|}{256} & \multicolumn{2}{|c|}{403} & \multicolumn{2}{|c|}{294} & \multicolumn{2}{|c|}{109} & & \\
\hline Family ownership (\%) & 18.55 & 15.35 & 12.01 & 8.50 & 12.76 & 9.48 & 9.96 & 5.99 & 6.50 & 6.78 \\
\hline Largest shareholder is family & 0.77 & 1.00 & 0.56 & 1.00 & 0.60 & 1.00 & 0.47 & 0.00 & 5.57 & 5.44 \\
\hline Descendant-in-law management & 0.00 & 0.00 & 0.11 & 0.00 & 0.10 & 0.00 & 0.14 & 0.00 & 5.66 & 5.54 \\
\hline Family representative director & 1.49 & 1 & 1.29 & 1 & 1.32 & 1 & 1.22 & 1 & 4.10 & 4.18 \\
\hline Family representative director ratio (\%) & 82.82 & 100 & 68.60 & 66.67 & 70.92 & 66.67 & 62.32 & 50 & 6.00 & 5.85 \\
\hline Tobin's $q$ & 1.66 & 1.48 & 1.42 & 1.27 & 1.42 & 1.29 & 1.42 & 1.22 & 3.28 & 3.90 \\
\hline Industry-adjusted Tobin's $q$ & 0.25 & 0.11 & 0.12 & -0.02 & 0.11 & -0.01 & 0.14 & -0.07 & 2.44 & 3.02 \\
\hline ROA (\%) & 8.61 & 7.98 & 7.03 & 6.51 & 7.28 & 6.69 & 6.36 & 6.01 & 5.22 & 5.67 \\
\hline Industry-adjusted ROA (\%) & 1.46 & 0.86 & 0.33 & 0.00 & 0.53 & 0.07 & -0.22 & -0.30 & 3.91 & 3.83 \\
\hline Assets (billion yen) & 11.80 & 4.69 & 15.90 & 5.40 & 14.90 & 5.05 & 18.50 & 6.14 & 1.32 & 0.95 \\
\hline Sales (billion yen) & 9.80 & 4.36 & 13.70 & 4.72 & 12.70 & 4.48 & 16.20 & 6.73 & 1.27 & 0.56 \\
\hline Leverage (\%) & 19.53 & 17.63 & 21.69 & 20.78 & 21.67 & 20.81 & 21.76 & 20.58 & 1.91 & 2.64 \\
\hline Beta & 0.86 & 0.86 & 0.92 & 0.93 & 0.90 & 0.91 & 0.96 & 1.00 & 4.99 & 5.38 \\
\hline Idiosyncratic risk & 0.09 & 0.09 & 0.09 & 0.09 & 0.09 & 0.09 & 0.09 & 0.09 & 1.08 & 2.40 \\
\hline Firm age since foundation & 42.25 & 41.00 & 76.74 & 66.00 & 61.91 & 62.00 & 116.72 & 92.00 & 9.78 & 15.86 \\
\hline Firm age since IPO & 13.25 & 8.00 & 25.54 & 28.00 & 23.82 & 28.00 & 30.17 & 29.00 & 13.60 & 12.02 \\
\hline $\begin{array}{l}\text { Ownership by largest shareholder } \\
\text { (except founding family) (\%) }\end{array}$ & 7.09 & 4.99 & 8.62 & 5.60 & 8.52 & 5.53 & 8.89 & 5.94 & 2.55 & 4.44 \\
\hline Related firm 1 & 0.07 & 0 & 0.10 & 0 & 0.09 & 0 & 0.12 & 0 & 1.36 & 1.36 \\
\hline Related firm 2 & 0.01 & 0 & 0.02 & 0 & 0.02 & 0 & 0.00 & 0 & 0.58 & 0.58 \\
\hline Affiliated firm & 0.00 & 0 & 0.01 & 0 & 0.01 & 0 & 0.02 & 0 & 0.87 & 0.87 \\
\hline
\end{tabular}

Notes: This table shows the summary statistics for family firms clustered by management generation in 1990. The sample consists of the firms managed by the founder or his descendant. The last two columns show the results of $t$-test and wilcoxon rank-sum test to compare the difference of means and medians between founder management and descendant management. Founder management is defined as those in which the founder is a president or chairman. Descendant management is defined as those in which the founder's descendant is a president or chairman after the founder retired. 
Table 7. Univariate Test: Tobin's $q$ and Family Firms

\begin{tabular}{|c|c|c|}
\hline & \multicolumn{2}{|c|}{ Manangement } \\
\hline & Nonfamily & Family \\
\hline \multicolumn{3}{|l|}{$\overline{\text { Panel A }}$} \\
\hline \multicolumn{3}{|l|}{ Largest shareholder is } \\
\hline Nonfamily & Nonfamily firm & Family firm (M) \\
\hline Mean Tobin's $q$ & 1.41 & $1.49 *$ \\
\hline Median Tobin's $q$ & 1.24 & $1.34 * *$ \\
\hline Sample size & 1121 & 236 \\
\hline Family & Family firm (O) & Family firm (M\&O) \\
\hline Mean Tobin's $q$ & 1.46 & $1.53^{* * *}$ \\
\hline Median Tobin's $q$ & 1.30 & $1.36^{* * *}$ \\
\hline \multirow[t]{3}{*}{ Sample size } & 38 & 423 \\
\hline & \multicolumn{2}{|c|}{ Manangement } \\
\hline & Founder & Descendant \\
\hline \multicolumn{3}{|l|}{ Panel B } \\
\hline \multicolumn{3}{|l|}{ Largest shareholder is } \\
\hline Nonfamily & Founder firm (M) & Descendant firm (M) \\
\hline Mean Tobin's $q$ & 1.43 & $1.51^{*}$ \\
\hline Median Tobin's $q$ & 1.28 & $1.36^{* *}$ \\
\hline Sample size & 59 & 177 \\
\hline Family & Founder firm (M\&O) & Descendant firm (M\&O) \\
\hline Mean Tobin's $q$ & $1.73 * * *$ & 1.35 \\
\hline Median Tobin's $q$ & $1.54 * * *$ & 1.21 \\
\hline Sample size & 197 & 226 \\
\hline
\end{tabular}

Notes: This table reports the mean and median Tobin's $q$ for various types of family firms and nonfamily firms in 1990. The sample consists of the firms listed on the First and Second Sections of the Stock Exchanges of Tokyo, Osaka, and Nagoya at the end of 1990, with financial firms and public utility firms excluded. Family management is defined as those in which the founder or his descendant is a president or chairman. Founder management is defined as those in which the founder is a president or chairman. Descendant management is defined as those in which the founder's descendant is a president or chairman after the founder retired. ${ }^{*}, * *$, and $* * *$ indicate that the difference of means and medians between each family firm and nonfamily firm is significance at the 10,5 , and 1 percent levels, respectively. To test the difference of medians, wilcoxon rank-sum test is used. 
Table 8. OLS Regressions: Tobin's $q$ and Family Firms

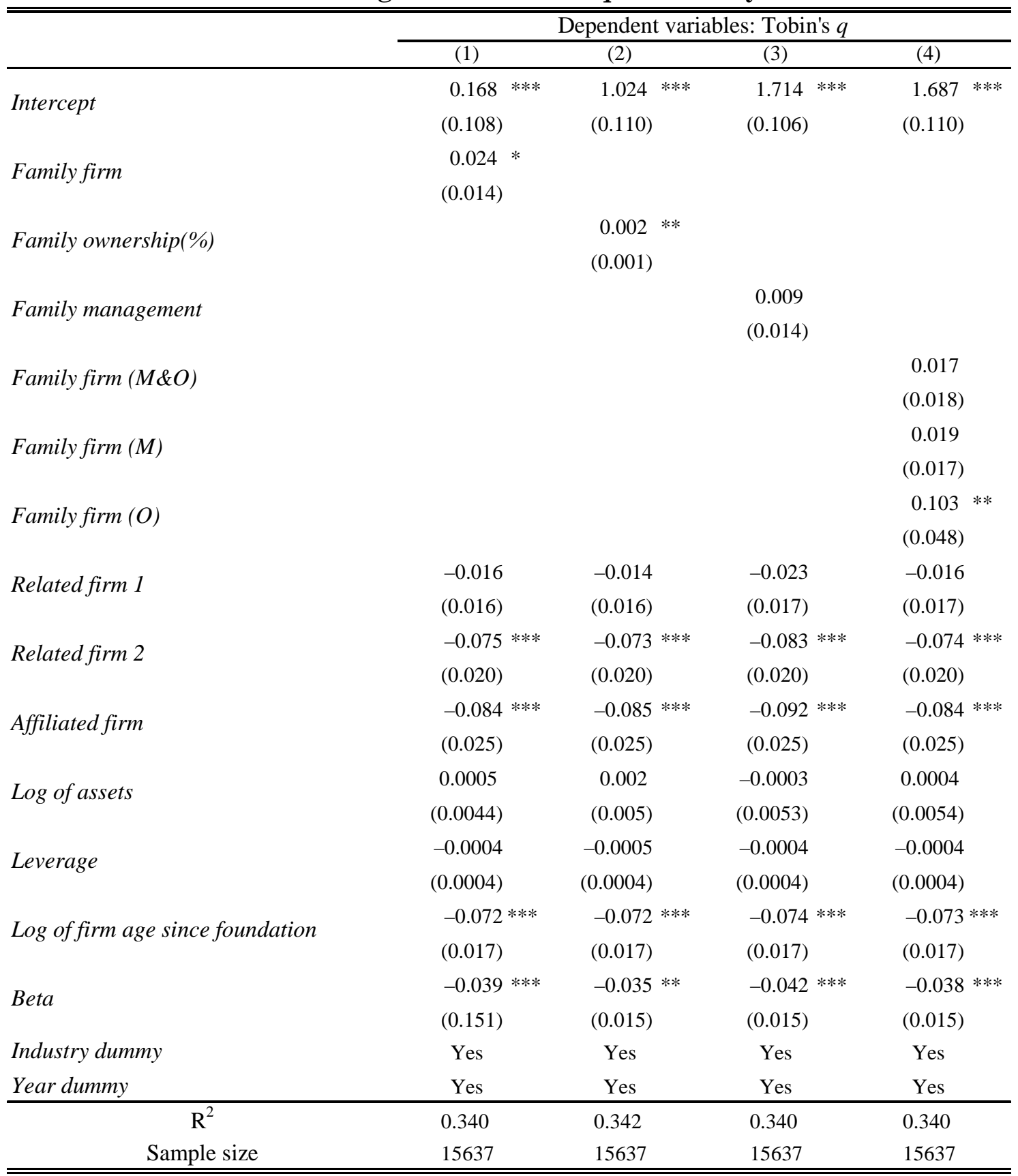

Notes: This table shows the results of OLS regressions with 15,590 firm-year observations. The sample consists of the firms listed on the First and Second Sections of the Stock Exchanges of Tokyo, Osaka, and Nagoya at the end of 1990, with financial firms and public utility firms excluded. The sample period is from 1990 to 1998. Firms that have a Tobin's $q$ below the 1st percentile or above the 99th percentile are excluded from regressions. In parentheses are robust standard errors corrected for clustering at the firm level. *, **, and $* * *$ indicate significance at the 10,5 , and 1 percent levels, respectively. 
Table 9. OLS Regressions: Tobin's $q$ and Family Firms

\begin{tabular}{|c|c|c|c|c|}
\hline & & pendent var & s: Tobin's $q$ & \\
\hline & (1) & (2) & (3) & (4) \\
\hline Intercept & $\begin{array}{l}1.607^{* * *} \\
(0.106)\end{array}$ & $\begin{array}{l}1.6022^{* * *} \\
(0.109)^{2}\end{array}$ & $\begin{array}{l}1.592^{* * *} \\
(0.109)^{* *}\end{array}$ & $\begin{array}{l}1.603 * * * \\
(0.110)\end{array}$ \\
\hline Founder management & $\begin{array}{l}0.116 * * * \\
(0.024)\end{array}$ & & & \\
\hline Descendant management & $\begin{array}{l}-0.031 * * \\
(0.015)\end{array}$ & & & \\
\hline Founder firm (M\&O) & & $\begin{array}{l}0.136 * * * \\
(0.027)\end{array}$ & $\begin{array}{l}0.135 * * * \\
(0.027)\end{array}$ & $\begin{array}{l}0.136^{* * *} \\
(0.027)^{*}\end{array}$ \\
\hline Founder firm (M) & & $\begin{array}{l}0.083 * \\
(0.044)\end{array}$ & $\begin{array}{c}0.083 * \\
(0.043)\end{array}$ & $\begin{array}{c}0.083 * \\
(0.044)\end{array}$ \\
\hline Family firm (O) & & $\begin{array}{l}0.107 * * \\
(0.477)\end{array}$ & $\begin{array}{l}0.106 * * \\
(0.048)\end{array}$ & $\begin{array}{l}0.107^{* *} \\
(0.048)\end{array}$ \\
\hline Descendant firm (M\&O) & & $\begin{array}{l}-0.050 * * \\
(0.020)\end{array}$ & $\begin{array}{l}-0.041 * * \\
(0.020)\end{array}$ & $\begin{array}{l}-0.043 * \\
(0.022)\end{array}$ \\
\hline Descendant firm (M) & & $\begin{array}{c}0.008 \\
(0.017)\end{array}$ & $\begin{array}{c}0.020 \\
(0.019)\end{array}$ & $\begin{array}{l}-0.001 \\
(0.020)\end{array}$ \\
\hline Descendant-in-law firm $(M \& O)$ & & & $\begin{array}{l}-0.079 * \\
(0.046)\end{array}$ & \\
\hline Descendant-in-law firm (M) & & & $\begin{array}{l}-0.099 * * * \\
(0.033)\end{array}$ & \\
\hline 3rd generation firm $(M \& O)$ & & & & $\begin{array}{l}-0.027 \\
(0.033)\end{array}$ \\
\hline 3rd generation firm $(M)$ & & & & $\begin{array}{c}0.030 \\
(0.036)\end{array}$ \\
\hline Control variables & Yes & Yes & Yes & Yes \\
\hline Industry dummy & Yes & Yes & Yes & Yes \\
\hline Year dummy & Yes & Yes & Yes & Yes \\
\hline $\mathrm{R}^{2}$ & 0.348 & 0.352 & 0.353 & 0.352 \\
\hline Sample size & 15637 & 15637 & 15637 & 15637 \\
\hline $\begin{array}{l}\text { Wald test of differences in model coeffic } \\
\text { Null hypothesis }\end{array}$ & & & & \\
\hline $\begin{array}{l}\text { Founder management }=\text { descendant } \\
\text { management }\end{array}$ & $\begin{array}{l}36.070 * * * \\
(0.000)\end{array}$ & & & \\
\hline $\begin{array}{l}\text { Founder firm }(M \& O)=\text { founder firm } \\
(M)\end{array}$ & & $\begin{array}{c}1.180 \\
(0.278)\end{array}$ & & \\
\hline $\begin{array}{l}\text { Descendant firm }(M \& O)=\text { descendant } \\
\text { Firm }(M)\end{array}$ & & $\begin{array}{l}8.090 \\
(0.005)\end{array}$ & & \\
\hline $\begin{array}{l}\text { Founder firm }(M \& O)=\text { descendant firm } \\
(M \& O)\end{array}$ & & $\begin{array}{l}40.930 * * * \\
(0.000)\end{array}$ & & \\
\hline $\begin{array}{l}\text { Founder firm }(M)=\text { descendant firm } \\
(M)\end{array}$ & & $\begin{array}{l}2.890 * \\
(0.090)\end{array}$ & & \\
\hline $\begin{array}{l}\text { Family firm }(O)=\text { descendant firm } \\
(M \& O)\end{array}$ & & $\begin{array}{l}10.440 * * \\
(0.001)\end{array}$ & & \\
\hline
\end{tabular}

Notes: Upper panel of this table shows the results of OLS regressions with 15,590 firm-year observations. The sample consists of the firms listed on the First and Second Sections of the Stock Exchanges of Tokyo, Osaka, and Nagoya at the end of 1990, with financial firms and public utility firms excluded. The sample period is from 1990 to 1998. Firms that have a Tobin's $q$ below the 1st percentile or above the 99th percentile are excluded from regressions. Control variables are related firm1, related firm2 and affiliated firm, log of assets, leverage, log of firm age since foundation and beta. In parentheses are robust standard errors corrected for clustering at the firm level. The lower panel shows the results of wald test to test the null hypothesis that the coefficients of each family firm are the same. In parentheses are $P$-values. In both panels, ${ }^{*}, * *$, and ${ }^{* * *}$ indicate significance at the 10,5 , and 1 percent levels, respectively. 
Table 10. Alternative Regressions: Tobin's $q$ and Family Firms

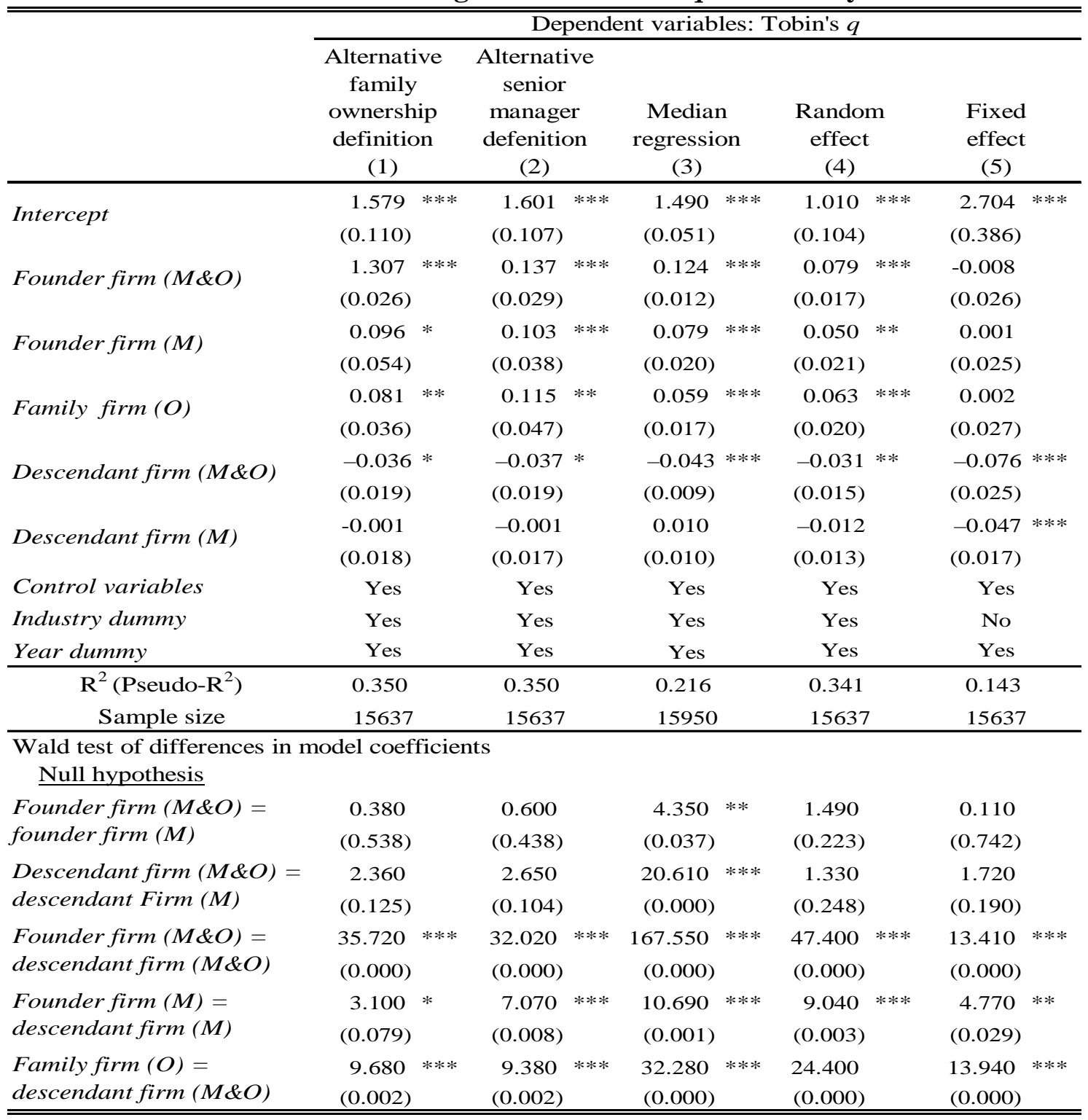

Notes: Upper panel of this table shows the results of regressions with 15,590 firm-year observations. The sample consists of the firms listed on the First and Second Sections of the Stock Exchanges of Tokyo, Osaka, and Nagoya at the end of 1990, with financial firms and public utility firms excluded. The sample period is from 1990 to 1998. Firms that have a Tobin's $q$ below the 1st percentile or above the 99th percentile are excluded from regressions of column (1), (2), (4) and (5). Control variables are related firm1, related firm2 and affiliated firm, log of assets, leverage, log of firm age since foundation and beta. In column (1) and (2), OLS regression is used. In column (1), founder firm $(M \& O)$ is a firm where the senior manager (president or chairman) is the founder, and the founding family owns $5 \%$ or more of the firm's equity. Founder firm $(M)$ is a firm where the senior manager is the founder, but the founding family owns below $5 \%$ of the firm's equity. Family firm $(O)$ is a firm where the founding family owns $5 \%$ or more of the firm's equity, but the senior manager is not a family member. Descendant firm (M\&O) is a firm where the senior manager (president or chairman) is the founder's descendant after the founder retired, and the founding family owns $5 \%$ or more of the firm's equity. Descendant firm $(M)$ is a firm where the senior manager (president or chairman) is the founder's descendant after the founder retired, but the founding family owns below 5\% of the firm's equity. In column (2), senior manager is defined as representative directors. Based on this alternative senior manager definition, family firm $(O)$, founder firm $(M \& O)$, founder firm $(M)$, descendant firm $(M \& O)$ and descendant firm $(M)$ are constructed. In parentheses are robust standard errors corrected for clustering at the firm level in column (1), (2), (4) and (5), and standard errors in column (3). The lower panel shows the results of wald test to test the null hypothesis that the coefficients of each family firm are the same. In parentheses are $P$-values. In both panels, $*, * *$, and $* * *$ indicate significance at the 10,5 , and 1 percent levels, respectively. 
Table 11. Performance Changes around Transitions of Family Firms

\begin{tabular}{|c|c|c|c|}
\hline \multirow[b]{2}{*}{ Transition } & \multicolumn{3}{|c|}{ "Change in industry-adjusted Tobin's q } \\
\hline & Mean & Median & Sample size \\
\hline $\begin{array}{l}\text { From founder firm }(M \& O) \\
\text { to descendant firm }(M \& O)\end{array}$ & $-0.107 * *$ & $-0.046 *$ & 55 \\
\hline $\begin{array}{c}\text { From founder firm }(M \& O) \\
\text { to family firm }(O)\end{array}$ & 0.163 & 0.118 & 25 \\
\hline Difference & $-0.270 * *$ & $-0.164 *$ & \\
\hline $\begin{array}{l}\text { From founder firm }(M) \\
\quad \text { to descendant firm }(M)\end{array}$ & -0.047 & -0.085 & 34 \\
\hline $\begin{array}{r}\text { From founder firm }(M) \\
\text { to nonfamily firm }\end{array}$ & -0.186 & -0.039 & 14 \\
\hline Difference & 0.139 & -0.047 & \\
\hline $\begin{array}{l}\text { From 2nd generation firm }(M \& O) \\
\text { to 3rd generation firm }(M \& O)\end{array}$ & -0.045 & 0.038 & 30 \\
\hline $\begin{array}{l}\text { From 2nd generation firm }(M \& O) \\
\text { to family firm }(O)\end{array}$ & -0.018 & -0.027 & 23 \\
\hline Difference & -0.026 & 0.065 & \\
\hline $\begin{array}{l}\text { From 2nd generation firm }(M) \\
\text { to 3rd generation firm }(M)\end{array}$ & -0.058 & -0.020 & 12 \\
\hline $\begin{array}{l}\text { From 2nd generation firm }(M) \\
\text { to nonfamily firm }\end{array}$ & -0.036 & -0.023 & 45 \\
\hline Difference & -0.021 & 0.004 & \\
\hline
\end{tabular}

Notes: This table shows the change in industry-adjusted Tobin's $q$ around transitions of family firms. Change in industry-adjusted Tobin's $q$ is defined as industry-adjusted Tobin's $q$ at two-years after the transition minus industry-adjusted Tobin's $q$ at two-years before the transition. Industry-adjusted Tobin's $q$ is defined as Tobin's $q$ minus industry median Tobin's $q .{ }^{*}, * *$, and $* * *$ indicate significantly different from zero at the 10, 5, and 1 percent levels, respectively. 
Table 12. Treatment Regressions: Tobin's $q$ and Family Firms

\begin{tabular}{|c|c|c|c|c|c|c|}
\hline Treatment dummy $=$ & $\frac{\text { Family firm }}{(1)}$ & $\begin{array}{c}\begin{array}{c}\text { Founder firm } \\
(M \& O)\end{array} \\
(2)\end{array}$ & $\begin{array}{c}\begin{array}{c}\text { Founder firm } \\
(M)\end{array} \\
(3)\end{array}$ & $\begin{array}{c}\text { Family firm } \\
\text { (O) } \\
(4)\end{array}$ & $\begin{array}{l}\text { Descendant } \\
\text { firm }(M \& O) \\
(5)\end{array}$ & $\begin{array}{c}\text { Descendant } \\
\text { firm }(M) \\
(6)\end{array}$ \\
\hline Intercept & $\begin{array}{l}1.174 \text { *** } \\
(0.096)\end{array}$ & $\begin{array}{l}0.759 * * * \\
(0.108)\end{array}$ & $\begin{array}{l}1.062 \text { *** } \\
(0.111)\end{array}$ & $\begin{array}{l}0.922 \text { *** } \\
(0.109)\end{array}$ & $\begin{array}{l}1.203 * * * \\
(0.104)\end{array}$ & $\begin{array}{l}0.920^{* * *} \\
(0.098)\end{array}$ \\
\hline Treatment dummy & $\begin{array}{l}0.328 * * * \\
(0.008)\end{array}$ & $\begin{array}{l}0.388 * * * \\
(0.014)\end{array}$ & $\begin{array}{l}0.412 \text { *** } \\
(0.028)\end{array}$ & $\begin{array}{l}0.395 \text { *** } \\
(0.022)\end{array}$ & $\begin{array}{l}-0.342 * * * \\
(0.014)\end{array}$ & $\begin{array}{l}0.294^{* * *} \\
(0.013)\end{array}$ \\
\hline Related firm 1 & $\begin{array}{c}0.003 \\
(0.006)\end{array}$ & $\begin{array}{l}-0.007 \\
(0.011)\end{array}$ & $\begin{array}{l}-0.023 * \\
(0.013)\end{array}$ & $\begin{array}{l}-0.014 \\
(0.013)\end{array}$ & $\begin{array}{l}-0.022 * * \\
(0.010)\end{array}$ & $\begin{array}{c}0.002 \\
(0.007)\end{array}$ \\
\hline Related firm2 & $\begin{array}{l}-0.014 * \\
(0.008)\end{array}$ & $\begin{array}{l}-0.036 * * \\
(0.015)\end{array}$ & $\begin{array}{l}-0.061 \quad * * * \\
(0.018)\end{array}$ & $\begin{array}{l}-0.053 * * * \\
(0.018)\end{array}$ & $\begin{array}{l}-0.043 * * * \\
(0.011)\end{array}$ & $\begin{array}{l}-0.034 * * * \\
(0.011)\end{array}$ \\
\hline Affiliated firm & $\begin{array}{l}-0.024 * * \\
(0.012)\end{array}$ & $\begin{array}{l}-0.056 * * * \\
(0.019)\end{array}$ & $\begin{array}{l}-0.068 * * * \\
(0.023)\end{array}$ & $\begin{array}{l}-0.044 * * * \\
(0.020)\end{array}$ & $\begin{array}{l}-0.044 * * * \\
(0.012)\end{array}$ & $\begin{array}{l}-0.019 \\
(0.015)\end{array}$ \\
\hline Log of assets & $\begin{array}{r}0.006 \\
(0.005)\end{array}$ & $\begin{array}{l}-0.003 \\
(0.006)\end{array}$ & $\begin{array}{l}-0.012 * * \\
(0.006)\end{array}$ & $\begin{array}{l}-0.007 \\
(0.006)\end{array}$ & $\begin{array}{l}-0.016 * * * \\
(0.006)\end{array}$ & $\begin{array}{l}-0.010 * \\
(0.005)\end{array}$ \\
\hline Leverage & $\begin{array}{l}-0.0001 \\
(0.0004)\end{array}$ & $\begin{array}{l}-0.0003 \\
(0.0005)\end{array}$ & $\begin{array}{l}0.00002 \\
(0.0005)\end{array}$ & $\begin{array}{l}-0.0001 \\
(0.0005)\end{array}$ & $\begin{array}{l}0.00025 \\
(0.0005)\end{array}$ & $\begin{array}{r}0.0005 \\
(0.0004)\end{array}$ \\
\hline $\begin{array}{l}\text { Log of firm age } \\
\text { since foundation }\end{array}$ & $\begin{array}{l}-0.009 \\
(0.006)\end{array}$ & $\begin{array}{l}-0.006 \\
(0.012)\end{array}$ & $\begin{array}{l}-0.027 \\
(0.017)\end{array}$ & $\begin{array}{l}-0.021 \\
(0.013)\end{array}$ & $\begin{array}{l}-0.026 * * * \\
(0.010)\end{array}$ & $\begin{array}{l}-0.015 * \\
(0.008)\end{array}$ \\
\hline Beta & $\begin{array}{l}0.026 * \\
(0.015)\end{array}$ & $\begin{array}{c}0.007 \\
(0.017)\end{array}$ & $\begin{array}{l}-0.018 \\
(0.017)\end{array}$ & $\begin{array}{l}-0.013 \\
(0.018)\end{array}$ & $\begin{array}{l}-0.044 * * \\
(0.017)\end{array}$ & $\begin{array}{l}-0.021 \\
(0.016)\end{array}$ \\
\hline $\begin{array}{l}\text { Industry dummy } \\
\text { Year dummy }\end{array}$ & $\begin{array}{l}\text { Yes } \\
\text { Yes }\end{array}$ & $\begin{array}{l}\text { Yes } \\
\text { Yes }\end{array}$ & $\begin{array}{l}\text { Yes } \\
\text { Yes }\end{array}$ & $\begin{array}{l}\text { Yes } \\
\text { Yes }\end{array}$ & $\begin{array}{l}\text { Yes } \\
\text { Yes }\end{array}$ & $\begin{array}{l}\text { Yes } \\
\text { Yes }\end{array}$ \\
\hline \multicolumn{7}{|l|}{ Treatment equation } \\
\hline Intercept & $\begin{array}{l}0.534 * \\
(0.295)\end{array}$ & $\begin{array}{l}-0.234 \\
(0.416)\end{array}$ & $\begin{array}{l}-0.608 * * * \\
(0.547)\end{array}$ & $\begin{array}{l}-0.845 * \\
(0.478)\end{array}$ & $\begin{array}{l}1.078 * * * \\
(0.365)\end{array}$ & $\begin{array}{l}-0.969 * * * \\
(0.313)\end{array}$ \\
\hline $\begin{array}{l}\text { Indutry-adjusted } \\
\text { Tobin's } q\end{array}$ & $\begin{array}{l}2.702 \text { *** } \\
(0.054)\end{array}$ & $\begin{array}{l}2.870 * * * \\
(0.075)\end{array}$ & $\begin{array}{l}3.016 * * * \\
(0.087)\end{array}$ & $\begin{array}{l}2.922 * * * \\
(0.099)\end{array}$ & $\begin{array}{l}-2.759 * * * \\
(0.071)\end{array}$ & $\begin{array}{l}2.957^{* * *} \\
(0.075)\end{array}$ \\
\hline $\begin{array}{l}\text { Number of } \\
\text { negative profit }\end{array}$ & $\begin{array}{l}-0.009 * * * \\
(0.003)\end{array}$ & $\begin{array}{l}-0.017^{* * *} \\
(0.007)\end{array}$ & $\begin{array}{l}-0.028 \text { *** } \\
(0.010)\end{array}$ & $\begin{array}{l}-0.007 \\
(0.005)\end{array}$ & $\begin{array}{l}-0.009 * * * \\
(0.003)\end{array}$ & $\begin{array}{l}-0.005 \\
(0.004)\end{array}$ \\
\hline Idiosyncratic risk & $\begin{array}{l}-0.374 \\
(0.232)\end{array}$ & $\begin{array}{r}0.498 \\
(0.443)\end{array}$ & $\begin{array}{r}0.620 \\
(0.843)\end{array}$ & $\begin{array}{r}0.558 \\
(0.434)\end{array}$ & $\begin{array}{l}-0.810^{* * *} \\
(0.381)\end{array}$ & $\begin{array}{l}0.637^{* *} \\
(0.311)\end{array}$ \\
\hline Log of assets & $\begin{array}{l}-0.020 \\
(0.017)\end{array}$ & $\begin{array}{r}0.013 \\
(0.023)\end{array}$ & $\begin{array}{c}0.004 \\
(0.029)\end{array}$ & $\begin{array}{c}0.019 \\
(0.026)\end{array}$ & $\begin{array}{l}-0.067 * * * \\
(0.021)\end{array}$ & $\begin{array}{c}0.024 \\
(0.018)\end{array}$ \\
\hline Leverage & $\begin{array}{c}0.001 \\
(0.001)\end{array}$ & $\begin{array}{r}0.001 \\
(0.002)\end{array}$ & $\begin{array}{l}-0.001 \\
(0.002)\end{array}$ & $\begin{array}{l}-0.0004 \\
(0.0016)\end{array}$ & $\begin{array}{c}0.002 \\
(0.002)\end{array}$ & $\begin{array}{l}-0.0007 \\
(0.0014)\end{array}$ \\
\hline $\begin{array}{l}\text { Log of firm age } \\
\text { since IPO }\end{array}$ & $\begin{array}{l}-0.091 * * * \\
(0.015)\end{array}$ & $\begin{array}{l}-0.196 * * * \\
(0.026)\end{array}$ & $\begin{array}{l}-0.105 * * * \\
(0.038)\end{array}$ & $\begin{array}{l}-0.069 * * * \\
(0.025)\end{array}$ & $\begin{array}{l}-0.014 \\
(0.022)\end{array}$ & $\begin{array}{c}0.001 \\
(0.025)\end{array}$ \\
\hline Beta & $\begin{array}{l}-0.116 * * \\
(0.048)\end{array}$ & $\begin{array}{l}-0.044 \\
(0.062) \\
\end{array}$ & $\begin{array}{r}0.038 \\
(0.079) \\
\end{array}$ & $\begin{array}{l}-0.060 \\
(0.104) \\
\end{array}$ & $\begin{array}{l}-0.154 * * * \\
(0.055)\end{array}$ & $\begin{array}{r}0.014 \\
(0.059) \\
\end{array}$ \\
\hline Log pseudolikelihood & -6830.91 & -3739.16 & -2852.04 & -3031.19 & -4525.12 & -3718.81 \\
\hline Wald chi-sq & 2952.97 & 991.54 & 368.25 & 534.49 & 22064.07 & 10177.98 \\
\hline Sample size & 15637 & 11171 & 10211 & 10278 & 11936 & 11460 \\
\hline
\end{tabular}

Notes: This table shows the results of treatment regressions. The upper panel includes the results from the outcome equation and the lower panel contains the estimates for the treatment equation. The treatment group is a dummy that equals one for family firms as a whole or for one of the five types of family firms. The outcome variable is Tobin's $q$. Sample firms are comprised of only the family firm in the category analyzed and nonfamily firms. Number of negative profit and idiosyncratic risk are used as the exogenous variable in the treatment equation model. Number of negative profit is the number of times before-tax after-interest profit is negative after an IPO. In parentheses are robust standard errors corrected for clustering at the firm level. *, **, and *** indicate significance at the 10,5 , and 1 percent levels, respectively. 


\section{Figure 1. Transition of Family Firms}

This figure shows the transitions of family firms from 1990 to 1994 and from 1994 to 1998. Transitions below three cases are abbreviated for viewability.

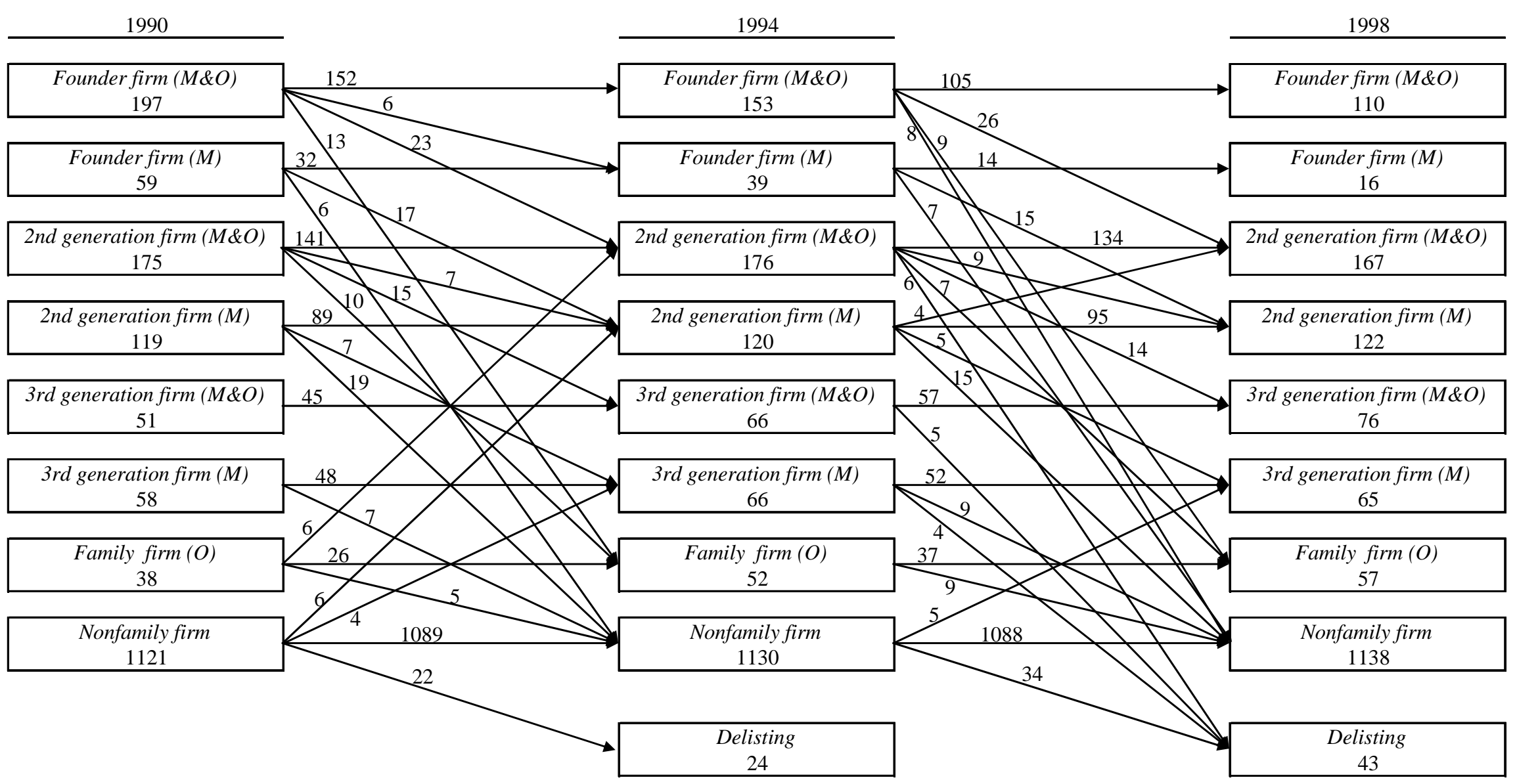

